\title{
WestVirginiaUniversity
}

THE RESEARCH REPOSITORY @ WVU

Graduate Theses, Dissertations, and Problem Reports

2018

\section{Growth media alternatives for mine refuse cap and cover systems}

Sitraka Jean d'Annie Rabemanjakasoa

Follow this and additional works at: https://researchrepository.wvu.edu/etd

\section{Recommended Citation}

Rabemanjakasoa, Sitraka Jean d'Annie, "Growth media alternatives for mine refuse cap and cover systems" (2018). Graduate Theses, Dissertations, and Problem Reports. 3982.

https://researchrepository.wvu.edu/etd/3982

This Problem/Project Report is protected by copyright and/or related rights. It has been brought to you by the The Research Repository @WVU with permission from the rights-holder(s). You are free to use this Problem/Project Report in any way that is permitted by the copyright and related rights legislation that applies to your use. For other uses you must obtain permission from the rights-holder(s) directly, unless additional rights are indicated by a Creative Commons license in the record and/ or on the work itself. This Problem/Project Report has been accepted for inclusion in WVU Graduate Theses, Dissertations, and Problem Reports collection by an authorized administrator of The Research Repository @ WVU. For more information, please contact researchrepository@mail.wvu.edu. 
Growth media alternatives for mine refuse cap and cover systems

Sitraka Jean d’Annie Rabemanjakasoa

Problem Report submitted to the

Benjamin M. Statler College of Engineering and Mineral Resources at West Virginia University

in partial fulfillment of the requirements for the degree of

\section{Master of Science}

in

Civil and Environmental Engineering

John Quaranta, Ph.D., P.E., Chair

Hema J. Siriwardane, Ph.D., P.E.

Leslie Hopkinson, Ph.D.

Lian-Shin Lin, Ph.D., P.E.

Department of Civil and Environmental Engineering

Morgantown, West Virginia

2018

Keywords: coal refuse, reclamation, revegetation, papermill sludge, sewage sludge, wood residue

Copyright 2018 Sitraka Rabemanjakasoa 


\begin{abstract}
Growth media alternatives for mine refuse cap and cover systems Sitraka Jean d’Annie Rabemanjakasoa
\end{abstract}

In 1999, Royal Scot Minerals based in Greenbrier County, West Virginia, USA went bankrupt and abandoned a 47-acre coal refuse pile, which currently presents environmental and economic issues. The primary objective of this problem report is to identify an effective approach to create a growth layer that establishes a sustainable vegetation on this pile.

Using available data in the relevant literature, this report evaluates topsoil substitutes using three materials: papermill sludge, sewage sludge and lumber mill waste application for coal refuse piles. Like papermill sludge, sewage sludge reduces erosion/sedimentation by improving the soil water holding capacity and decreases the surface runoff, to limit the acid mine drainage generation by lowering the soil $\mathrm{pH}$, and to raise the soil organic matter, which is fundamental for revegetation. Although they present some similarities, sewage sludge offers greater advantages that may be more cost efficient given that the supply is located closer to the site and only requires additional lime/limestone for successful revegetation.

Overall, when comparing these three substitutes in the context of the current conditions and objectives at the Royal Scot site, it appears that sewage sludge offers the best results, followed by the papermill sludge. Lumber mill waste also presents a potential material for coal refuse revegetation; however, further research is necessary to confirm its fitness. 


\section{ACKNOWLEDGMENTS}

The author wishes to express appreciation to all of those who supported her in any respect during the completion of this report.

First off, I wish to express special thanks to Dr. Quaranta, my academic advisor, for his sound technical assistance and his wise council and guidance.

Sincere thanks are also extended to Dr. Hema J. Siriwardane, Dr. Leslie Hopkinson, and Dr. Lian-Shian Li for serving as members of my Advisor and Examining Committee.

I am also grateful to my officemates Iuri Santos, Levi Cyphers, and Rogan Park for sharing their expertise on the Royal scot site to me.

I would like to share the credit of my work with my best friend Ashley Clayton for her constant assistance throughout the completion of my study.

And last but not least, I owe my deepest gratitude to my family (my three children - Iriela, Iriana, Iraina, my husband - Gilbert, my mother - Honorine, and my brother - Haingo) for their support and encouragement during my journey in the USA.

This report is dedicated to my father Rabearimanana J. Firmin L. Even if he is not part of this world anymore, he has been an inspiration to further my studies. 


\section{TABLE OF CONTENTS}

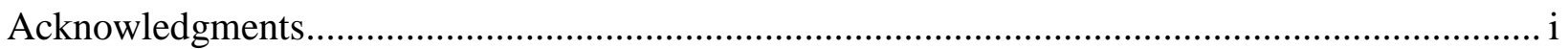

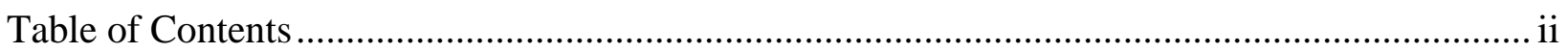

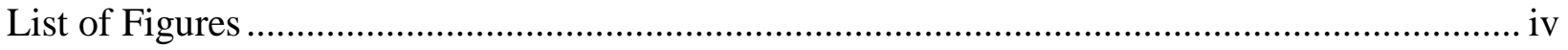

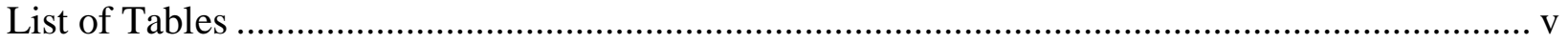

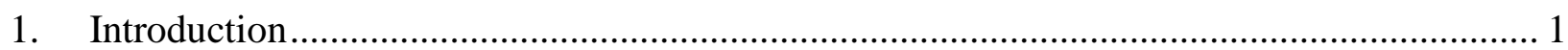

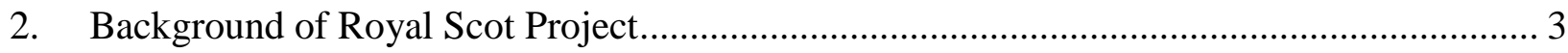

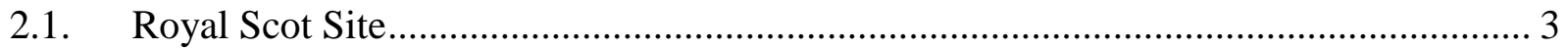

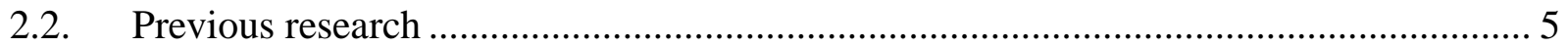

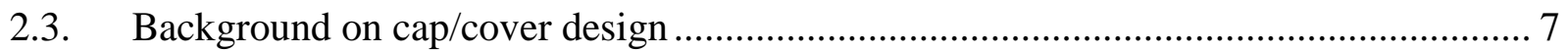

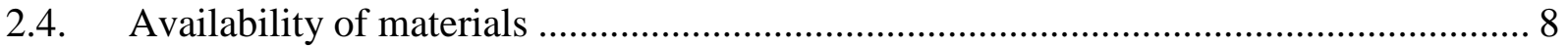

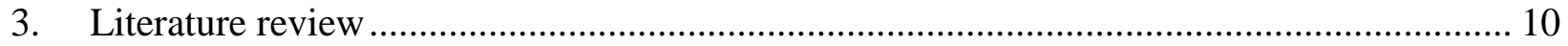

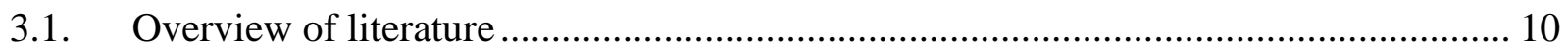

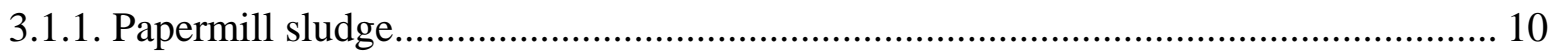

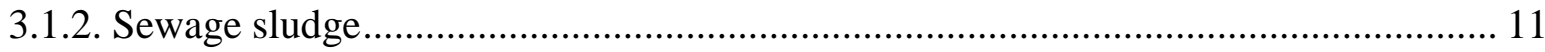

3.1.3. Lumber mill waste (or wood residue) ................................................................. 11

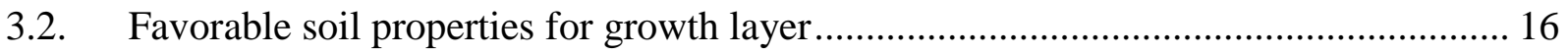

3.3. Literature review of papermill sludge for coal refuse reclamation............................. 18

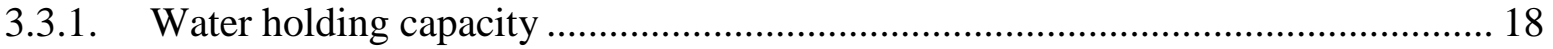

3.3.2. Effect on drainage and soil $\mathrm{pH}$................................................................ 19

3.3.3. Acid Mine Drainage and leachate quality.................................................... 19

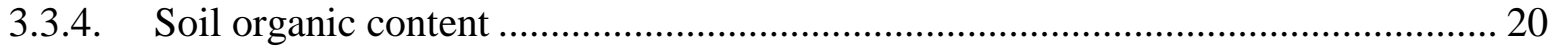

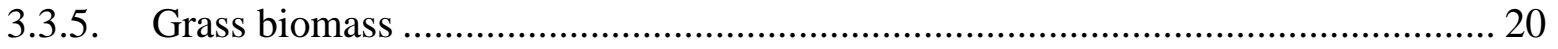


3.3.6. Suggested application rate of sludge for revegetation purposes ........................ 21

3.3.7. Species and seed mixture used for revegetation .......................................... 23

3.4. Literature review of sewage sludge for coal refuse reclamation ............................. 25

3.4.1. Water holding capacity, surface runoff and temperature .................................. 25

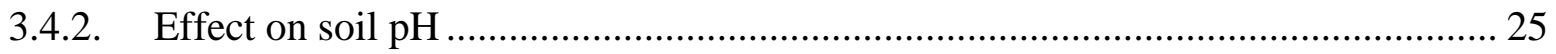

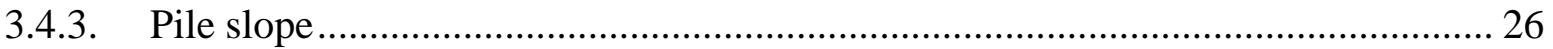

3.4.4. Acid Mine Drainage and leachate quality.................................................... 26

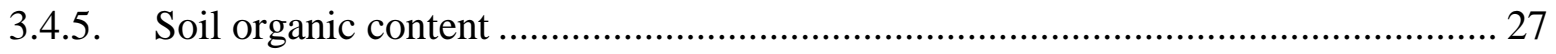

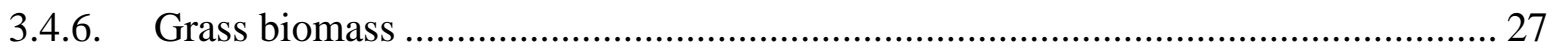

3.4.7. Nutrients............................................................................................ 28

3.4.8. Suggested application rate of sludge for revegetation purposes ......................... 29

3.4.9. Species and seed mixture used for revegetation .............................................. 30

3.5. Literature review of lumber mill waste (or wood residue or wood waste) for coal refuse

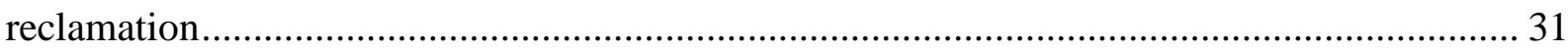

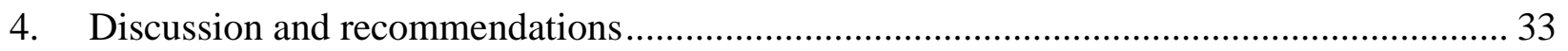

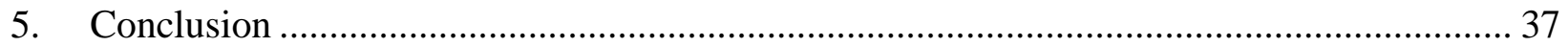

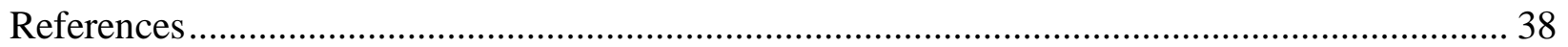




\section{LIST OF FIGURES}

Figure 1. Location of Royal Scot site .............................................................................. 3

Figure 2. Abandoned coal refuse at the Royal Scot site ................................................... 4

Figure 3. AMD treatment ponds at Royal Scot site ......................................................... 5

Figure 4. Coal refuse cover and capping system ......................................................... 7

Figure 5 Royal Scot project location and three nearest source of sewage sludge ....................... 9

Figure 6. Royal Scot project location and two nearest source of lumber mill waste.................... 9

Figure 7. Test plot showing the ongoing revegetation research by Cyphers et al. (in press) ....... 23 


\section{LIST OF TABLES}

Table 1. Geotechnical properties of papermill sludge, shale, and MGro ${ }^{\circledR}$................................. 6

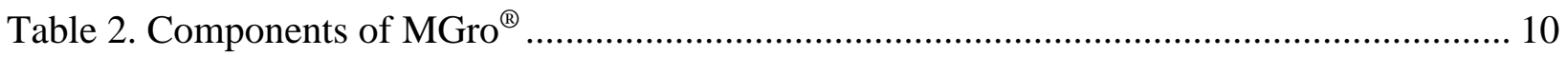

Table 3. Typical papermill and sewage sludges properties ................................................. 12

Table 4. Evaluation of the papermill sludge references....................................................... 14

Table 5. Evaluation of the sewage sludge references ......................................................... 15

Table 6. Grass growth media vs. coal refuse properties .................................................... 17

Table 7. Effects of papermill sludge application on water holding capacity............................. 18

Table 8. Liming benefit of papermill sludge application...................................................... 19

Table 9. Papermill sludge application on AMD and leachate quality ..................................... 20

Table 10. Effects of papermill sludge application on grass biomass ...................................... 21

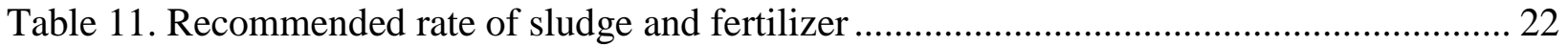

Table 12. Species and seed mixture used for revegetation .................................................. 24

Table 13. Liming benefit of sewage sludge application ..................................................... 26

Table 14. Effects of sewage sludge application on soil organic content ................................. 27

Table 15. Effects of sewage sludge application on grass biomass ........................................... 28

Table 16. Effects of sewage sludge application on grass nutrients........................................ 28

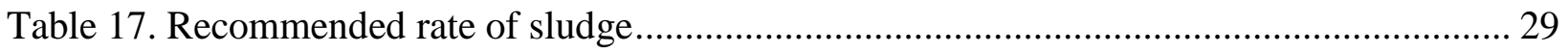

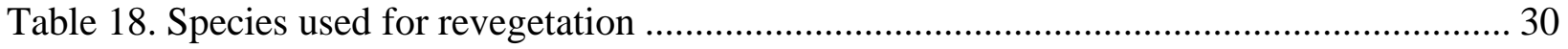

Table 19. Particles size distribution of bentonite spoil vs. coal refuse .................................... 31

Table 20. Papermill vs. sewage sludge for application at Royal Scot ..................................... 33

Table 21. Best practices for field application of papermill and sewage sludge......................... 35 


\section{INTRODUCTION}

In the Appalachian region of the United States, the availability of topsoil - an essential material for surface mining reclamation - is limited, so finding effective substitutes are critical to reclaim the region's mine spoils. This report focuses on three topsoil substitutes: the application of papermill sludge, sewage sludge and lumber mill waste. These methods were chosen because they appear to be three of the most effective ways for promoting long-term, self-sustaining vegetation and addressing the most immediate problem of Acid Mine Drainage (AMD). AMD comes from the exposure of metal sulfide minerals to oxygen and water such as pyrites and other sulfide ores (Akcil \& Koldas, 2006; Wurzburger \& Overton, 1997). According to the Environmental Protection Agency (EPA), AMD mainly comes from abandoned coal mines and active mines.

The purpose of this report is to perform a comprehensive literature review of scientific research to reclaim and revegetate the Royal Scot site, which, until now, remains an abandoned coal refuse pile. The EPA describes coal refuse as waste products of coal mining, physical coal cleaning, and coal preparation operations containing coal, matrix material, clay, and other organic and inorganic material.

The objective of this report is to identify what methods and techniques might be the most effective in establishing a growth base for native grasses, an important part of the revegetation, in general, and specifically, the reclamation process. It also considers the possible ways of shifting from the current AMD mitigation approach to a source control approach, which is believed to be the most economical solution. Revegetation refers to the process of planting bare areas (raw mineral soils) to perennial plants and less often annual plants (USDA, 2005).

This report draws from several articles that offer information about the case study (Royal Scot site) and information about best practices to revegetate shale. It details the strengths and limitations of the application of papermill, sewage sludge and wood residue in terms of addressing the issues and accomplishing the long-term goals at the Royal Scot project. The first section of this report provides a background of the project and this report. The second section outlines the literature review related to papermill sludge, sewage sludge, wood residue and their 
application on coal refuse reclamation. And lastly, some recommendations and conclusions are presented. 


\section{BACKGROUND OF ROYAL SCOT PROJECT}

\subsection{Royal Scot Site}

Royal Scot Minerals, Inc. was a coal company in Greenbrier County, West Virginia, USA

(Figure 1) that had mine permit that covered more than 400 acres. It is the operator of the Anjean mines, which started extracting coal in 1925.

Almost 75 years later (in 1999), the company went bankrupt for reasons that are still not confirmed and, as a result, closed. According to the West Virginia Department of Environmental Protection (WVDEP), the company abandoned a 47-acre coal refuse pile, containing approximately 3.5 million tons of coal refuse (Figure 2).

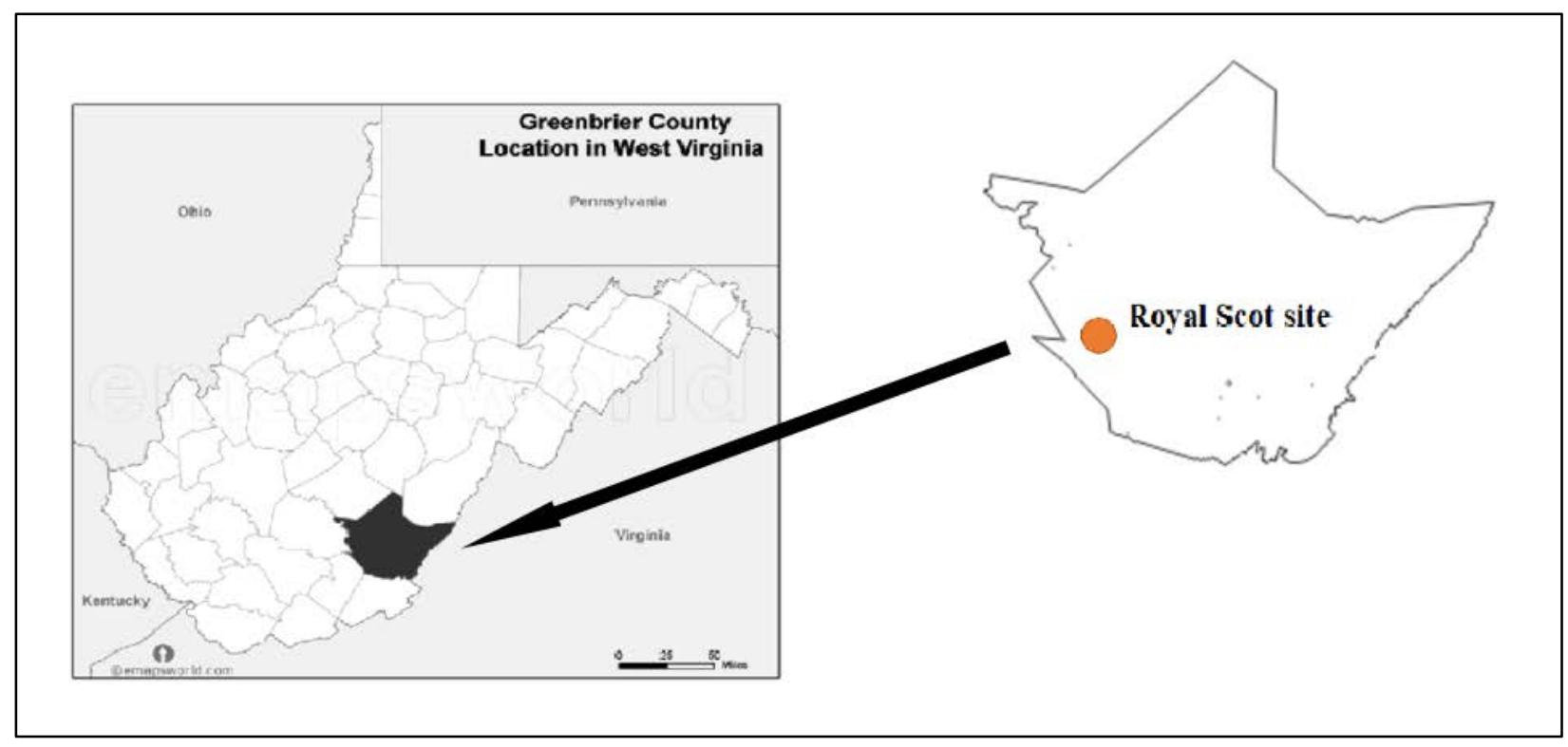

Figure 1. Location of Royal Scot site 


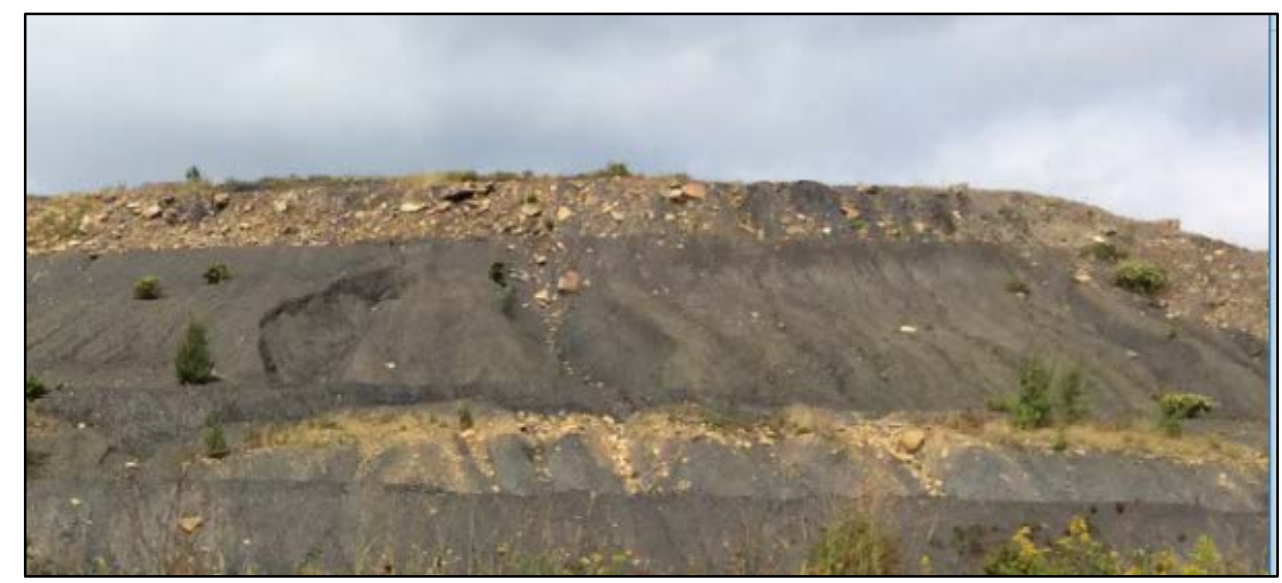

Figure 2. Abandoned coal refuse at the Royal Scot site Photo courtesy of Levi Cyphers

Coal refuse is a by-product resulting from the ore separation process, mainly composed of rock fragments and a small amount of coal (D'Appolonia, 2009; Tolikonda, 2010). It can be either coarse refuse or fine refuse, depending on the particle size (SME, 1973). According to Stevens (2016), the pile material at Royal Scot site falls under the first category which is a coarse coal refuse classified by ASTM D-2487 as a poorly graded sand with gravel (American Society for Testing and Materials, 1991). It presents a grain size ranging from greater than two inches (50.8 $\mathrm{mm})$ to fines $(>0.074 \mathrm{~mm})$.

The coal refuse pile at Royal Scot is a pyritic shale refuse containing elements such as iron and manganese, which can contribute to water contamination (Santos, 2017). Environmental problems are erosion and sedimentation, which can contribute to landslides. One of the most urgent issues is the acid mine drainage (AMD) that is currently taking place. Ward (2001) notes that AMD is not only an ecological concern but also an economical issue by reducing the value of recreational fish species and outdoor recreation. This is concerning to the surrounding environment and community. For example, Little Clear Creek, which is located near the site is a renowned fishing area. If this site is left as-is, meaning without any proper closure, it remains a risk to this area and others.

In general, there are two techniques used to manage AMD:

- Source control: prevent or minimize the generation of AMD 
- Migration measure: minimize the environmental impact of the contaminated streams and rivers. (Johnson \& Hallberg, 2005)

The current approach being employed at Royal Scot is the "mitigation measure" by applying active chemical processing (Figure 3). What this report intends to look at is the possibility of shifting away from mitigation to a source control approach by revegetating and blending with the mineral waste.

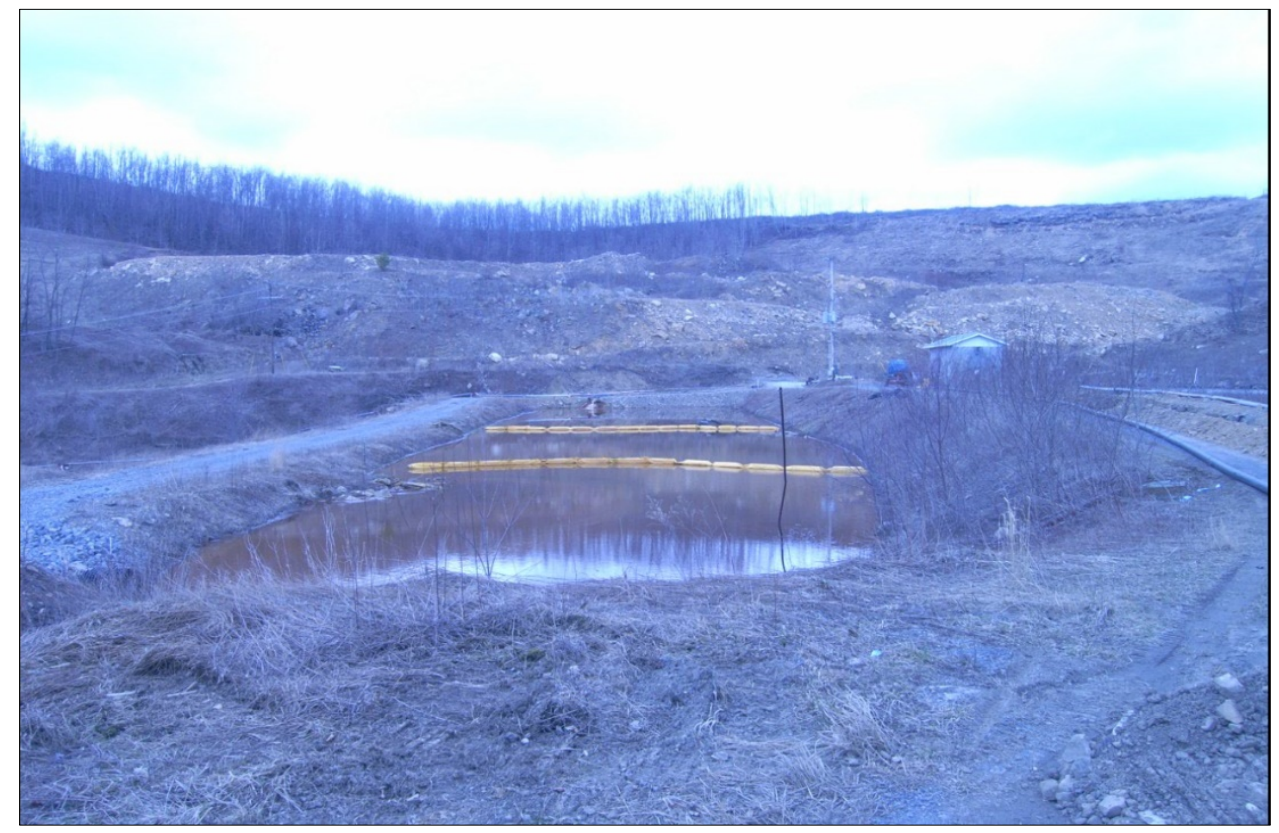

Figure 3. AMD treatment ponds at Royal Scot site

Photo courtesy of Dr. John Quaranta

\subsection{Previous research}

The Royal Scot site has been a subject of several research studies. Table 1 summarizes the outcome of the previous research conducted on the Royal Scot project. It compiles the properties of (i) papermill sludge found in the literature, (ii) shale at the Royal Scot site, and (iii) a Short Paper Fiber (SPF) which is marketed as MGro ${ }^{\circledR}$. 
Table 1. Geotechnical properties of papermill sludge, shale, and MGro ${ }^{\circledR}$

\begin{tabular}{|c|c|c|c|c|c|c|}
\hline $\begin{array}{l}\text { Geotechnical properties/ } \\
\text { materials }\end{array}$ & $\begin{array}{l}\text { Papermill sludge } \\
\text { from literature }\end{array}$ & $\begin{array}{l}\text { Coarse coal } \\
\text { refuse } \\
\text { Shale }\end{array}$ & $\begin{array}{l}\text { Short paper } \\
\text { fiber MGro }{ }^{\circledR}\end{array}$ & $\begin{array}{l}60 / 40 \\
\text { Shale/ } \\
\text { MGro }{ }^{\circledR} \text { blend }\end{array}$ & $\begin{array}{l}80 / 20 \\
\text { Shale/ } \\
\text { MGro }{ }^{\circledR} \text { blend }\end{array}$ & $\begin{array}{l}80 / 20 \\
\text { Shale/ } \\
\text { MGro }{ }^{\circledR} \text { blend }\end{array}$ \\
\hline & $\begin{array}{l}\text { (Moo-Young \& } \\
\text { Zimmie, 1996) }\end{array}$ & $\begin{array}{l}\text { (Stevens, } \\
\text { 2016) }\end{array}$ & $\begin{array}{l}\text { (Stevens, } \\
\text { 2016) }\end{array}$ & (Stevens, 2016) & (Stevens, 2016) & (Park, 2017) \\
\hline Water content (\%) & $150-250$ & 6.28 & 128.58 & N/A & N/A & N/A \\
\hline $\begin{array}{l}\text { Grain Size Distribution } \\
\text { Uniformity coefficient, } \mathrm{Cu} \\
\text { Coefficient of gradation, Cc }\end{array}$ & N/A & $\begin{array}{l}12.93 \\
0.84\end{array}$ & $\begin{array}{l}12.93 \\
0.84\end{array}$ & $\begin{array}{l}6.33 \\
1.72\end{array}$ & $\begin{array}{l}7.00 \\
1.29\end{array}$ & N/A \\
\hline Organic content (\%) & $35-56$ & N/A & N/A & N/A & N/A & N/A \\
\hline Specific gravity & $1.80-2.08$ & 2.19 & $1.92-2.21$ & N/A & N/A & $\mathrm{N} / \mathrm{A}$ \\
\hline $\begin{array}{l}\text { Atterberg limits } \\
\text { Plastic Limit, PL (\%) } \\
\text { Liquid Limit, LL (\%) } \\
\text { Plasticity Index, PL (\%) }\end{array}$ & $\begin{array}{l}\text { High } \\
94-147 \\
218-297 \\
77-191\end{array}$ & $\begin{array}{l}26.1 \\
30.1 \\
4\end{array}$ & N/A & N/A & N/A & N/A \\
\hline Hydraulic conductivity $(\mathrm{cm} / \mathrm{s})$ & $\begin{array}{l}3.4 \times 10^{-8}-1.06 \mathrm{x} \\
10^{-7}\end{array}$ & $\begin{array}{l}3.5 \times 10^{-7}- \\
4.2 \times 10^{-4}\end{array}$ & N/A & $8.61 \times 10^{-4}$ & N/A & $3.34 \times 10^{-4}$ \\
\hline $\begin{array}{l}\text { Effective angle of internal } \\
\text { friction (degree) }\end{array}$ & $25-40^{\circ}$ & $41.4-43.8$ & N/A & 30.16 & N/A & 13.23 \\
\hline Effective cohesion $(\mathrm{kPa})$ & $2.8-9.0$ & $16.99-25.6$ & N/A & 1.92 & N/A & N/A \\
\hline
\end{tabular}

N/A: Not available or not tested 


\subsection{Background on cap/cover design}

The state of West Virginia is fully responsible for the AMD treatment at Royal Scot because the site is currently considered as no owner/claimer. The treatment is costly which incites the WVDEP to look for a better alternative that is cost-effective and environmentally friendly. Hence, the WVDEP in partnership with West Virginia University Department of Civil and Environmental Engineering have conducted research based on a geomorphic landform design and a cap/cover system at the existing Royal Scot coal refuse pile (Santos, 2017).

Santos (2017) studied the 3-Dimensional design and evaluated a hydraulic barrier for the coal refuse at Royal Scot. To do so, two different layers have been described as the desired cover and capping system (Refer to Figure 4) for the project:

- Hydraulic barrier/Impermeable layer: it is a 60 -cm layer.

- Growth layer: it is a 30-cm vegetative layer.

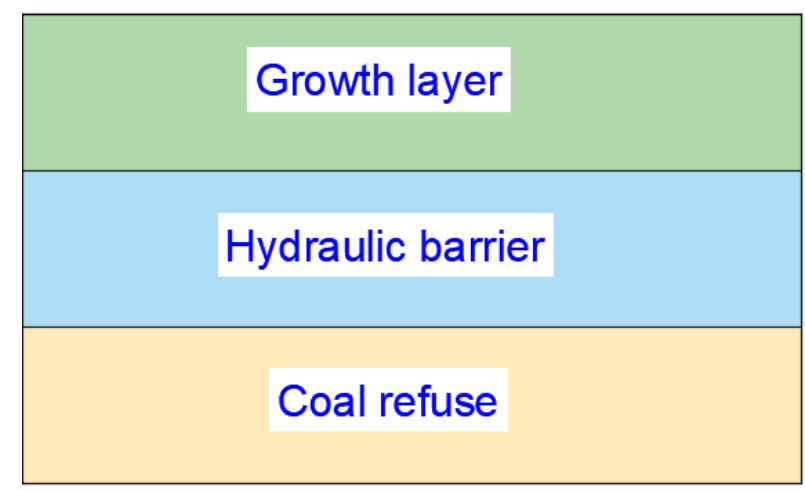

Figure 4. Coal refuse cover and capping system

(Santos et al., 2017)

A cap and cover system completes two main roles: minimizing the water precipitation infiltration from the surface while maintaining the geotechnical stability of the pile, and making the revegetation easier. Explanation of the individual layers follows: 
- Growth layer: it provides a medium for vegetation growth. It is generally composed of a coal refused blended with other amendments. (Hopkinson et al., 2017; Lorimer, 2016; Stevens, 2016)

- Hydraulic barrier: it primarily limits the precipitation infiltration into the refuse fill. It is composed of a heavily compacted coal refuse.

Three studies Park (2017) and Santos (2017) and Stevens (2016) have evaluated the hydraulic barrier design whereas this report attempts to review the literature related to the growth layer.

\subsection{Availability of materials}

Three materials are analyzed in this report: MGro $^{\circledR}$, sewage sludge, and lumber mill waste. The MGro $^{\circledR}$ material is produced at the WestRock paper mill in Covington Virginia, about 55 miles south of the Royal Scot site. Three sewage treatment plants (Figure 5) are identified around the project site which can be potential sources of sewage sludge for reclamation application:

- Summersville Wastewater Treatment, 221 Canvas Nettie Rd, Summersville, WV 26651 - About 40 miles

- Waste Water Treatment Plant, Staff Dr, Richwood, WV 26261 - About 25 miles

- $\quad$ Sewage Treatment Plant, Glen Ray Rd, Alderson, WV 24910 - About 30 miles. 


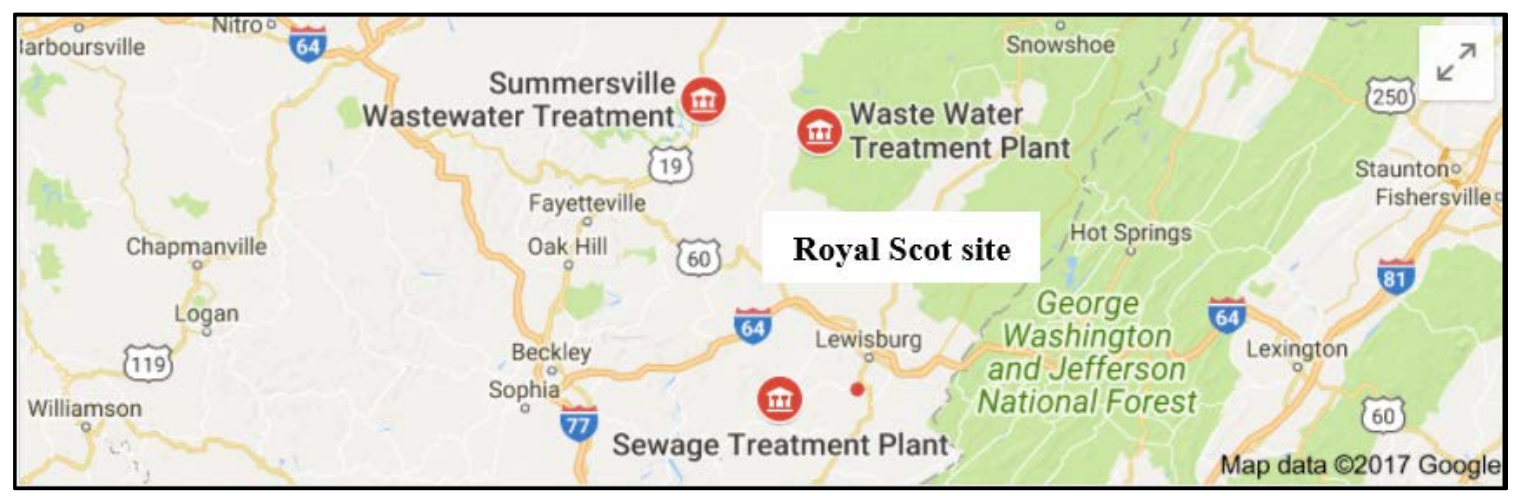

Figure 5 Royal Scot project location and three nearest source of sewage sludge

Source: Google. (n.d.) [Google Maps Royal Scot project location and three nearest source of sewage sludge] Retrieved July 12, 2017, from https://www.google.com/maps

Two lumber mills (Figure 6) are identified to be potential source of wood waste for reclamation application around the project site:

- Meadow River Lumber Company, Snake Island, Rainelle, WV 25962 - About 13 miles

- $\quad$ AWP Smoot Sawmill, 9144 Grassy Meadows Road, Smoot, WV 24977 - About 15 miles

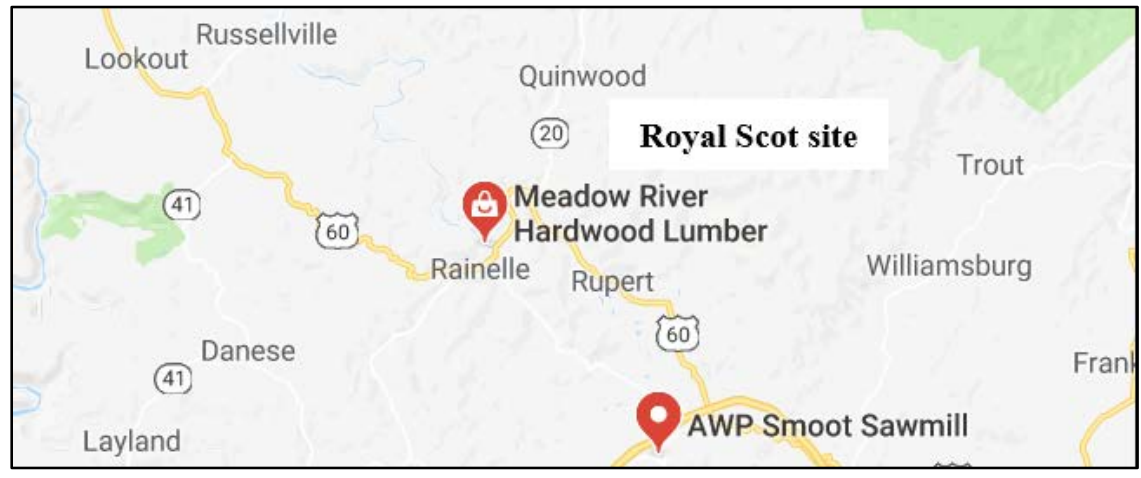

Figure 6. Royal Scot project location and two nearest source of lumber mill waste Source: Google. (n.d.) [Google Maps Royal Scot project location and two nearest source of lumber mill waste] Retrieved December 6, 2017, from https://www.google.com/maps 


\section{LITERATURE REVIEW}

\subsection{Overview of literature}

Addressing the issues at the Royal Scot site will require the restoration of the growth layer. Shale can be difficult to revegetate because it has a low $\mathrm{pH}$, high salt water content and a poor waterholding capacity (Daniels, Stewart, \& Zipper, 1996; Joost, Olsen, \& Jones, 1987; Li \& Daniels, 1997). The three methods that show promise of restoring the growth layer (Figure 4) are the application of papermill sludge, sewage sludge and wood residue.

\subsubsection{Papermill sludge}

Papermill sludge contains Short Paper Fiber (SPF), which is a co-product that is manufactured in the papermaking process. It is composed primarily by wood fiber, lime and clay, as well as excess organisms (Laubenstein \& Field, 1994). The SPF product from WestRock paper mill, commercially called MGro ${ }^{\circledR}$, is a mixture of solids from primary clarification (85\%) and residual from biological wastewater (15\%). Table 2 summarizes the main components of MGro ${ }^{\circledR}$, taken from the Material Safety Data Sheet (Greg Cox, personal correspondence).

Table 2. Components of MGro ${ }^{\circledR}$

\begin{tabular}{|l|c|}
\hline \multicolumn{1}{|c|}{ Component } & Percent \\
\hline Water & $50-60$ \\
\hline Residual solids (containing the following) & $40-50$ \\
\hline Pulp Mill Waste Solids & $15-30$ \\
\hline Cellulose Wood Fiber & $10-30$ \\
\hline Fly and/or Wood Ash ${ }^{(a)}$ & $<5$ \\
\hline Crystalline Silica, Quartz & $0.1-10$ \\
\hline Titanium Dioxide & $<3$ \\
\hline Kaolin Clay & Varies \\
\hline Calcium Carbonate & Varies \\
\hline Calcium Phosphate & $<5$ \\
\hline
\end{tabular}

(a) Fly and/or Wood Ash may have the following elements present as oxides or hydroxides: aluminum, calcium, iron, magnesium, potassium, titanium and silicon. 


\subsubsection{Sewage sludge}

Sewage sludge is a by-product produced during sewage treatment of industrial or municipal wastewater. It refers to the solid residue that remains after sewage is treated, such as reducing concentrations of easily decomposable organic materials. Its characteristics depends on the sewage quality and the processes (Singh \& Agrawal, 2008). In general, sewage sludge contains: organic compounds, macronutrients, a wide range of micronutrients, non-essential trace metals, organic micro pollutants, and microorganisms (Kulling, 2001).

\subsubsection{Lumber mill waste (or wood residue)}

Lumber mill waste (or wood residue) relates to the primary timber processing mill residues (McKeever, D.B. 2004). It is mainly composed of bark, wood chips, and sawdust. For instance, a wood residue from a sawmill in northeastern Wyoming consists of: $45 \%$ of bark, $20 \%$ of woodchips, and 35\% of sawdust (Smith, Schuman, De Puit, \& Sedbrook, 1985).

These advantages make sludges an interesting option for soil application. However, their application as soil amendments may also present other unintended risks to the environment and to worker safety. Alvarenga et al. (2015) and Singh and Agrawal (2008) found that:

- Sewage sludge application may contribute to $\mathrm{NH}_{3}$ (ammonia) emissions, potentially contamination with pathogenic microorganisms, and increase bioavailability of heavy metals

- Papermill sludge application may generates high $\mathrm{N}_{-} \mathrm{NO}_{3}{ }^{-}$concentrations which leached from soils and contaminate the superficial and underground water

Also, the Material Safety Data Sheets for wood residue products show that they contain combustible dust particulate. During the handling process, the particulate may form combustible dust concentrations in the air. Above that, coal refuse has a high surface temperature which can be a source of ignition. Both phenomena may lead to a risk of deflagration (combustion without detonation) which is not wanted for grass growth. 
Based on the literature and for application as growth layer at the Royal Scot site, it has been found that these methods and materials are:

- Cost effective and environmentally sustainable (Tordoff et al., 2000)

- $\quad$ May reduce the cost of waste disposal (Izu et al., 1997)

- May increase soil fertility (Sheoran, Sheoran, \& Poonia, 2010)

- May minimize Acid Mine Drainage (AMD) infiltration (Daniels et al., 1995; Maltby, 2005) and therefore reduce the cost of AMD treatment (Laubenstein, 2004)

- Can increase the $\mathrm{pH}$ and the organic matter content of the soil (Vasconcelos \& Cabral, 1993)

Table 3 presents the typical physical and geotechnical properties of both papermill and sewage sludge.

Table 3. Typical papermill and sewage sludges properties

\begin{tabular}{|l|l|l|}
\hline Parameters & Papermill sludge & Sewage sludge \\
\hline Origin of sludges & Seven local paper mill sludges & $\begin{array}{l}\text { Sewage sludge disposed in a pit } \\
\text { at Changan landfill, Chengdu, } \\
\text { China }\end{array}$ \\
\hline Initial water content (\%) & $150-250$ & $210-790$ \\
\hline Organic content (\%) & $35-56$ & $18.5-51.8$ \\
\hline Specific gravity & $1.80-2.08$ & - \\
\hline Grain Size Distribution & - & $\begin{array}{l}30 \% \text { of silt-size grains } \\
45 \% \text { of clay-size grains }\end{array}$ \\
\hline Plastic limit, PL (\%) & $94-143$ & 106 \\
\hline Liquid limit, LL (\%) & $218-297$ & 353 \\
\hline Plasticity index, PI & $77-191$ & - \\
\hline Consolidation & $\begin{array}{l}\text { Paper sludge is highly } \\
\text { compressible }\end{array}$ & $\begin{array}{l}\text { Compression index } \\
\text { Cc }=0.25-0.85\end{array}$ \\
\hline $\begin{array}{l}\text { Effective angle of internal } \\
\text { friction (degrees) }\end{array}$ & $25^{\circ}-40^{\circ}$ & $10^{\circ}-15^{\circ}$ \\
\hline Effective cohesion (kPa) & $2.8-9.0$ & - \\
\hline
\end{tabular}

Source: (Moo-Young \& Zimmie, 1996; Zhan et al., 2014) 
Eight articles were reviewed for relevance to this report. The period date for the references spans from 1983 to 2006.

These publications were chosen because they address:

- the reclamation practice of mine refuse disposal

- the establishment of vegetation on disturbed land especially on coal mine refuse

- the application of either papermill sludge or sewage sludge for revegetation purpose

The references used are not recent because of two reasons:

- Sludges are currently used as a "constituent in landfill covers or roadbeds" (Simpson \& Zimmie, 2005) rather than in promoting revegetation for growth layers.

- The topic "revegetation of coal refuse material using sludges" is currently not studied due to the lack of research funding from the mining companies and regulatory agencies.

Table 4 and 5 evaluate the major articles that were surveyed related to papermill and respectively sewage sludge application. They present an overview of each reference, highlighting the objective, the method used, and the sludge application. 
Table 4. Evaluation of the papermill sludge references

\begin{tabular}{|c|c|c|c|c|}
\hline & $\begin{array}{l}\text { (Li \& Daniels, } \\
\text { 1997) }\end{array}$ & $\begin{array}{l}\text { (Daniels et al., } \\
\text { 1996) }\end{array}$ & $\begin{array}{l}\text { (Camberato, } \\
\text { Gagnon, Angers, } \\
\text { Chantigny, \& Pan, } \\
\text { 2006) }\end{array}$ & $\begin{array}{l}\text { (Laubenstein, } \\
\text { 2004) }\end{array}$ \\
\hline Objective & $\begin{array}{l}\text { "Determine if a } \\
\text { papermill sludge } \\
\text { product could be } \\
\text { successfully } \\
\text { utilized to reclaim } \\
\text { coal processing } \\
\text { waste materials". }\end{array}$ & $\begin{array}{l}\text { "Review problems } \\
\text { associated with } \\
\text { stabilization and } \\
\text { revegetation of } \\
\text { coal refuse } \\
\text { disposal areas and } \\
\text { suggests strategies } \\
\text { for their successful } \\
\text { long-term } \\
\text { reclamation and } \\
\text { closure". }\end{array}$ & $\begin{array}{l}\text { Summarize the } \\
\text { effect of the } \\
\text { addition of pulp } \\
\text { and papermill } \\
\text { sludges and sludge } \\
\text { composts on soil } \\
\text { properties and on } \\
\text { crop responses. }\end{array}$ & $\begin{array}{l}\text { Prove that SPF } \\
\text { is a marketed } \\
\text { product which } \\
\text { helps AMD } \\
\text { generation from } \\
\text { coal refuse. }\end{array}$ \\
\hline Method & $\begin{array}{l}\text { Experience the } \\
\text { application of lime } \\
\text { fiber mulch and } \\
\text { fertilizer-N on coal } \\
\text { refuse reclamation }\end{array}$ & $\begin{array}{l}\text { Guidelines of coal } \\
\text { refuse reclamation }\end{array}$ & Literature review & $\begin{array}{l}\text { Case study of } \\
\text { two reclamation } \\
\text { site }\end{array}$ \\
\hline Application & $\begin{array}{l}\text { Reclamation of } \\
\text { coal refuse }\end{array}$ & $\begin{array}{l}\text { Stabilization and } \\
\text { reclamation of coal } \\
\text { refuse }\end{array}$ & $\begin{array}{l}\text { Land application } \\
\text { of pulp and } \\
\text { papermill by- } \\
\text { products }\end{array}$ & $\begin{array}{l}\text { Pollution } \\
\text { prevention in } \\
\text { the mining } \\
\text { industry }\end{array}$ \\
\hline $\begin{array}{l}\text { Site/Area of } \\
\text { application }\end{array}$ & Southwest Virginia & $\begin{array}{l}\text { Appalachian coal } \\
\text { fields }\end{array}$ & Not mentioned & $\begin{array}{l}\text { Coal mining } \\
\text { areas in the } \\
\text { Appalachian } \\
\text { region }\end{array}$ \\
\hline
\end{tabular}


Table 5. Evaluation of the sewage sludge references

\begin{tabular}{|c|c|c|c|c|}
\hline & $\begin{array}{l}\text { (Pietz, Carlson, } \\
\text { Peterson, Zenz, \& } \\
\text { Lue-Hing, 1989) }\end{array}$ & (Joost et al., 1987) & $\begin{array}{l}\text { (Seaker \& Sopper, } \\
\text { 1983) }\end{array}$ & (Sopper, 1992) \\
\hline Objective & $\begin{array}{l}\text { "Report the effects } \\
\text { of sewage sludge, } \\
\text { lime, gypsum on } \\
\text { coal refuse } \\
\text { material" }\end{array}$ & $\begin{array}{l}\text { "Evaluate } \\
\text { amendment of } \\
\text { acid coal refuse" }\end{array}$ & $\begin{array}{l}\text { "Demonstrate that } \\
\text { municipal sludge } \\
\text { can be used to } \\
\text { return strip-mined } \\
\text { land and deep- } \\
\text { mine refuse to } \\
\text { potential } \\
\text { agricultural use" }\end{array}$ & $\begin{array}{l}\text { "Investigate the } \\
\text { use of municipal } \\
\text { sewage sludge in } \\
\text { reclamation and } \\
\text { revegetation of } \\
\text { drastically } \\
\text { disturbed land" }\end{array}$ \\
\hline Method & $\begin{array}{l}\text { Experience the } \\
\text { application of } \\
\text { amendments on } \\
\text { coal refuse } \\
\text { reclamation }\end{array}$ & $\begin{array}{l}\text { "Deep } \\
\text { incorporation of } \\
\text { dried sewage } \\
\text { sludge and/or } \\
\text { limestone on acid } \\
\text { coal refuse (gob)" }\end{array}$ & $\begin{array}{l}\text { Sludge application } \\
\text { and monitoring } \\
\text { system }\end{array}$ & Literature review \\
\hline Application & $\begin{array}{l}\text { Coal refuse } \\
\text { reclamation }\end{array}$ & $\begin{array}{l}\text { Establishment of } \\
\text { forage grasses }\end{array}$ & $\begin{array}{l}\text { Vegetation } \\
\text { establishment }\end{array}$ & $\begin{array}{l}\text { Reclamation and } \\
\text { Revegetation }\end{array}$ \\
\hline $\begin{array}{l}\text { Site/Area of } \\
\text { application }\end{array}$ & $\begin{array}{l}\text { Fulton county, } \\
\text { Illinois }\end{array}$ & Southern Illinois & Pennsylvania & US \\
\hline
\end{tabular}




\subsection{Favorable soil properties for growth layer}

A successful revegetation mainly depends on the properties of the growth media. A growth medium is a solid, liquid or semi-solid designed to support the growth of microorganisms or cells (Madigan \& Martinko, 2006). According to the Food and Agriculture Organization of the United Nations ( Retrieved from http://www.fao.org/soils-portal/about/all-definitions/en/ on Jan 15, 2018), soil is the natural medium for the growth of plants.

Among others, the following summarizes the most important characteristics of soil that impact grass growth (Stichler, 2002):

- Temperature: minimum $40-42^{\circ} \mathrm{F}$ for cool season grasses and $60-65^{\circ} \mathrm{F}$ for warn season grasses.

- Texture: Compared to sandy soil, clay particles have higher water holding capacity, higher cation exchange capacity (CEC), and therefore more fertile. However, sand particles provide greater amount of oxygen for root growth in comparison to clay.

- Nutrients/Fertilizer: Nitrogen is the most often deficient.

For most warm season grasses, N-P-K ratio of 4-1-3 or 50-15-40 pounds is suggested to produce a ton of forage. Sludges and wood residue are great sources of nitrogen nutrient.

- Salinity: Low concentration of salt is desirable for grass roots development.

- $\mathbf{p H}$ : too high or too low $\mathrm{pH}$ is not appropriate for grass growth. Optimum $\mathrm{pH}$ for most grass is 6.5 to 7.0 .

- Organic matter: high level of organic matter is needed.

Table 6 shows that the properties of coal refuse present unfavorable conditions for grass growth. 
Table 6. Grass growth media vs. coal refuse properties

\begin{tabular}{|c|c|c|}
\hline Soil properties & $\begin{array}{l}\text { Favorable soil properties for grass } \\
\text { growth }\end{array}$ & Coal refuse properties \\
\hline Temperature & 40 to $65^{\circ} \mathrm{F}$ & High summer heat loads \\
\hline Texture & $\begin{array}{l}\text { Sandy: great amount of oxygen } \\
\text { Clay: - High water holding capacity } \\
\text { - High CEC }\end{array}$ & $\begin{array}{l}\text { Coarse texture } \\
\text { - Great amount of oxygen available } \\
\text { - Low water holding capacity } \\
\text { - Low CEC }\end{array}$ \\
\hline Nutrients & $\begin{array}{l}\text { Sufficient N-P-K is desirable. } \mathrm{N} \text { is the } \\
\text { most often deficient. }\end{array}$ & Deficient in available $\mathrm{P}$ \\
\hline Salinity & Low concentration of salt & High salt content \\
\hline $\mathrm{pH}$ & 6.5 to 7.0 & 3.0 to 8.3 \\
\hline Organic matter & High & Low \\
\hline
\end{tabular}

Source: (Li \& Daniels, 1997; Stewart \& Daniels, 1992; Stichler, 2002) 


\subsection{Literature review of papermill sludge for coal refuse reclamation}

This section examines how papermill sludge has been found to address the problems of shale (high surface temperature, low water holding capacity, low soil and drainage $\mathrm{pH}$, low organic content, etc...) and how it can promote revegetation and reduce AMD.

\subsubsection{Water holding capacity}

Camberato et al. (2006) and Li and Daniels (1997) affirm that sludge application on shale improves water holding capacity and infiltration resulting in surface moderate temperature, no waterlogging and/or runoff. As a confirmation, Laubenstein (2004) states that a SPF topsoil has $300 \%$ more water holding capacity compared to regular topsoil where $90 \%$ to $95 \%$ water is available for plant growth. These benefits definitely reduce irrigation requirement which is a valuable benefit on cost reduction (Camberato et al., 2006), refer to Table 7.

Table 7. Effects of papermill sludge application on water holding capacity

\begin{tabular}{|c|c|c|c|c|}
\hline & $\begin{array}{l}\text { (Li \& Daniels, } \\
\text { 1997) }\end{array}$ & $\begin{array}{l}\text { (Daniels et al., } \\
\text { 1996) }\end{array}$ & $\begin{array}{l}\text { (Camberato et al., } \\
\text { 2006) }\end{array}$ & $\begin{array}{l}\text { (Laubenstein, } \\
\text { 2004) }\end{array}$ \\
\hline $\begin{array}{l}\text { Water holding } \\
\text { capacity after } \\
\text { sludge } \\
\text { application }\end{array}$ & $\begin{array}{l}\text { No waterlogging } \\
\text { and/or runoff } \\
\text { Improved } \\
\text { infiltration and } \\
\text { water holding } \\
\text { capacity } \\
\text { Moderate surface } \\
\text { temperature }\end{array}$ & $\begin{array}{l}\text { Combined refuse } \\
\text { (coarse plus fine) in } \\
\text { the final } \\
\text { revegetation } \\
\text { surface is desirable } \\
\text { Less than 1-foot } \\
\text { layer is enough to } \\
\text { establish grasses } \\
\text { Improved water- } \\
\text { supply }\end{array}$ & $\begin{array}{l}\text { Increased soil water } \\
\text { holding capacity } \\
\text { Increased plant } \\
\text { available water } \\
\text { Reduced irrigation } \\
\text { requirement }\end{array}$ & $\begin{array}{l}\text { High moisture } \\
\text { holding } \\
\text { capacity - } \\
\text { exceeding } \\
\text { 300\% over a } \\
\text { high-quality } \\
\text { virgin topsoil. } \\
\text { "SPF topsoil is } \\
90 \% \text { to } 95 \% \text { of } \\
\text { the water held } \\
\text { is available to } \\
\text { the growing } \\
\text { cover as } \\
\text { compared to } \\
\text { only 60\% to } \\
65 \% \text { using } \\
\text { native soils". }\end{array}$ \\
\hline
\end{tabular}




\subsubsection{Effect on drainage and soil $\mathrm{pH}$}

Laubenstein (2004) illustrates a drainage $\mathrm{pH}$ change from 2.8 to 9 in three months following an SPF addition. Apart from increasing the $\mathrm{pH}, \mathrm{Li}$ and Daniels (1997) highlights that it also stabilizes the soil pH. Hence, Daniels et al. (1996) accentuate the importance of papermill sludge on acidic soils reclamation in terms of liming benefit, refer to Table 8 .

Table 8. Liming benefit of papermill sludge application

\begin{tabular}{|l|l|l|l|l|}
\hline & $\begin{array}{l}\text { Li \& Daniels, } \\
\text { 1997) }\end{array}$ & $\begin{array}{l}\text { (Daniels et al., } \\
\text { 1996) }\end{array}$ & $\begin{array}{l}\text { (Camberato et al., } \\
\text { 2006) }\end{array}$ & $\begin{array}{l}\text { (Laubenstein, } \\
\text { 2004) }\end{array}$ \\
\hline $\begin{array}{l}\text { Liming benefit } \\
\text { after papermill } \\
\text { sludge } \\
\text { application }\end{array}$ & $\begin{array}{l}\text { Increase and } \\
\text { stabilize soil pH }\end{array}$ & Not mentioned & Increase soil pH & $\begin{array}{l}\text { Increase in } \\
\text { drainage pH - } \\
\text { from 2.8 to 9 in } \\
\text { three months. }\end{array}$ \\
\hline
\end{tabular}

\subsubsection{Acid Mine Drainage and leachate quality}

According to Daniels et al. (1996), it is very likely that acidic shales will produce AMD in the Appalachian region. The references acknowledge that the application of papermill sludge on shale can treat/reduce AMD and improve water quality.

Li and Daniels (1997) indicate that papermill sludge application would improve leachates quality resulting in higher $\mathrm{pH}$ and lower toxic metals. Apart from papermill sludge, Daniels et al. (1996) bring up that addition of lime is also beneficial for a long-term AMD control. And more importantly, Laubenstein (2004) specifies a 80\% AMD treatment cost reduction following SPF addition, refer to Table 9 . 
Table 9. Papermill sludge application on AMD and leachate quality

\begin{tabular}{|c|c|c|c|c|}
\hline & $\begin{array}{l}\text { (Li \& Daniels, } \\
\text { 1997) }\end{array}$ & $\begin{array}{l}\text { (Daniels et al., } \\
\text { 1996) }\end{array}$ & $\begin{array}{l}\text { (Camberato et al., } \\
\text { 2006) }\end{array}$ & $\begin{array}{l}\text { (Laubenstein, } \\
\text { 2004) }\end{array}$ \\
\hline AMD & $\begin{array}{l}\text { Treat acid- } \\
\text { forming materials } \\
\text { Reduce } \\
\text { groundwater } \\
\text { contamination - } \\
\text { leachates higher } \\
\text { in pH and lower } \\
\text { in toxic metals }\end{array}$ & $\begin{array}{l}\text { AMD unavoidable } \\
\text { in Appalachian } \\
\text { region } \\
\text { Vegetative cover } \\
\text { reduces acid } \\
\text { drainage } \\
\text { Bulk blending of } \\
\text { lime is long-term } \\
\text { solution to control } \\
\text { AMD }\end{array}$ & Not mentioned & $\begin{array}{l}\text { AMD reduced } \\
\text { and water } \\
\text { quality } \\
\text { improved in } \\
\text { areas capped } \\
\text { with SPF } \\
\text { 80\% reduction } \\
\text { in AMD } \\
\text { treatment cost }\end{array}$ \\
\hline
\end{tabular}

\subsubsection{Soil organic content}

According to Camberato et al. (2006), high rate sludge application results in a permanent effect on supplying soil organic matter compared to low rate application. Also, they comment that sludge application improves soil physical properties: it lowers the bulk density, provide a greater soil aggregation, and mainly it increases the soil organic matter.

Papermill sludges are mainly composed of cellulose fiber as organic content: approximately 1535\% hemicellulose, 40-45\% cellulose, and 20-30\% lignin (Camberato et al., 2006), while shale is practically composed of zero organic content. Hence, the application of papermill sludge on shale would help compensate this organic content gap.

\subsubsection{Grass biomass}

Li and Daniels (1997) conclude that yields of biomass increase on area where papermill sludge and low N-fertilizer rate are applied. In contrary, yields decrease on areas where high-rate Nfertilizer and no-papermill sludge are applied.

From their review, when applying papermill sludge as soil amendments, Camberato et al. (2006) affirm that yields are higher with N-fertilizer than without it, refer to Table 10. 
Table 10. Effects of papermill sludge application on grass biomass

\begin{tabular}{|l|l|l|l|l|}
\hline & $\begin{array}{l}\text { Li \& Daniels, } \\
\text { 1997) }\end{array}$ & $\begin{array}{l}\text { (Daniels et al., } \\
\text { 1996) }\end{array}$ & $\begin{array}{l}\text { (Camberato et al., } \\
\text { 2006) }\end{array}$ & $\begin{array}{l}\text { (Laubenstein, } \\
\text { 2004) }\end{array}$ \\
\hline Grass biomass & $\begin{array}{l}\text { Yields increase } \\
\text { on applied } \\
\text { papermill sludge } \\
\text { area and the } \\
\text { 0/low N fertilizer } \\
\text { area. Inversely, } \\
\text { they decrease on } \\
\text { high rate N } \\
\text { fertilizer } \\
\text { application and } \\
\text { no papermill } \\
\text { sludge area. }\end{array}$ & Not mentioned & $\begin{array}{l}\text { Yields are higher } \\
\text { when papermill } \\
\text { sludge is applied } \\
\text { with N fertilizer, } \\
\text { compared papermill } \\
\text { sludge alone. }\end{array}$ & Not mentioned \\
& & & \\
\hline
\end{tabular}

\subsubsection{Suggested application rate of sludge for revegetation purposes}

Daniels et al. (1996) argue that fertilizer is a must for revegetation of shale. In addition, Camberato et al. (2006) state that papermill sludge combined with fertilizers proved a source of nutrients N-P-K. However, the latter do not mention any recommended rates. Li and Daniels (1997) note that to promote revegetation, high papermill sludge rate has a positive impact but high N-fertilizer has a negative impact.

Three different rates were mentioned in the literature for a successful vegetation establishment on shale:

1. Li and Daniels (1997) recommend:

- $112 \mathrm{Mg} / \mathrm{ha}$ papermill sludge,

- $112 \mathrm{~kg} / \mathrm{ha} \mathrm{N}$-fertilizer

- Balanced P and K fertilization

2. Daniels et al. (1996) recommend:

- 1000 to $1500 \mathrm{lb} / \mathrm{ac}$ papermill sludge (1120.85 to $1681.28 \mathrm{~kg} / \mathrm{ha}$ )

- $150 \mathrm{lb} / \mathrm{ac} \mathrm{N}+$ additional $\mathrm{N}$ fertilizer in successive years (168.13 kg/ha)

- $350 \mathrm{lb} / \mathrm{ac} \mathrm{P}$ as $\mathrm{P}_{2} \mathrm{O}_{5}(392.29 \mathrm{~kg} / \mathrm{ha})$

- $100 \mathrm{lb} / \mathrm{ac} \mathrm{K}$ as $\mathrm{K}_{2} \mathrm{O}(112.08 \mathrm{~kg} / \mathrm{ha})$ 
3. Laubenstein (2004) recommendation using specifically SPF:

- $75 \%$ SPF

- $25 \%$ shale

- Proper nutrients

This proportion was successful for revegetation and especially for AMD treatment.

The recommendations from literature are different, depending on the material used and goals to be reached. Considering the case of Royal Scot project which have the following constraints:

- Goals of papermill sludge use: revegetate shale and AMD treatment

- Availability of material: SPF

The above recommendations suggest that the rate 75\% SPF, 25\% shale, plus proper nutrients would be successful, refer to Table 11 .

Table 11. Recommended rate of sludge and fertilizer

\begin{tabular}{|c|c|c|c|c|}
\hline & $\begin{array}{l}\text { (Li \& Daniels, } \\
\text { 1997) }\end{array}$ & $\begin{array}{l}\text { (Daniels et al., } \\
\text { 1996) }\end{array}$ & $\begin{array}{l}\text { (Camberato et al., } \\
\text { 2006) }\end{array}$ & (Laubenstein, 2004) \\
\hline $\begin{array}{l}\text { Rate of } \\
\text { sludge and } \\
\text { fertilizer }\end{array}$ & $\begin{array}{l}\text { High papermill } \\
\text { sludge rate has a } \\
\text { positive impact } \\
\text { High N-fertilizer } \\
\text { rate results in } \\
\text { negative impact } \\
\text { Recommendation } \\
\text { short and long-term: } \\
112 \mathrm{Mg} / \text { ha } \\
\text { papermill sludge } \\
112 \mathrm{~kg} / \text { ha } \mathrm{N}- \\
\text { fertilizer } \\
\text { Balanced P and } \mathrm{K} \\
\text { fertilization }\end{array}$ & $\begin{array}{l}\text { Fertilizer is required } \\
\text { for revegetation of } \\
\text { refuse } \\
\text { Recommendation } \\
\text { for direct seeding: } \\
1000 \text { to } 1500 \mathrm{lb} / \mathrm{ac} \\
\text { papermill sludge } \\
150 \mathrm{lb} / \mathrm{ac} \mathrm{N}+ \\
\text { additional N } \\
\text { fertilizer in } \\
\text { successive years } \\
350 \mathrm{lb} / \mathrm{ac} \mathrm{P} \text { as } \mathrm{P}_{2} \mathrm{O}_{5} \\
100 \mathrm{lb} / \mathrm{ac} \mathrm{K} \text { as } \mathrm{K}_{2} \mathrm{O}\end{array}$ & $\begin{array}{l}\text { Rate not mentioned } \\
\text { Papermill sludge } \\
\text { combined/or not } \\
\text { with fertilizers } \\
\text { provide N, P, K for } \\
\text { crops }\end{array}$ & $\begin{array}{l}75 \% \text { SPF, 25\% } \\
\text { shale, nutrients }\end{array}$ \\
\hline
\end{tabular}

Ongoing research by Cyphers et al. (in press) at the Royal Scot site uses Shale/SPF rate of 80/20 and 60/40 for vegetation establishment and especially AMD treatment. Compared to the 75\% 
SPF rate suggested by Laubenstein (2004), this rate is relatively low which can result in a significant cost reduction if the result is conclusive.

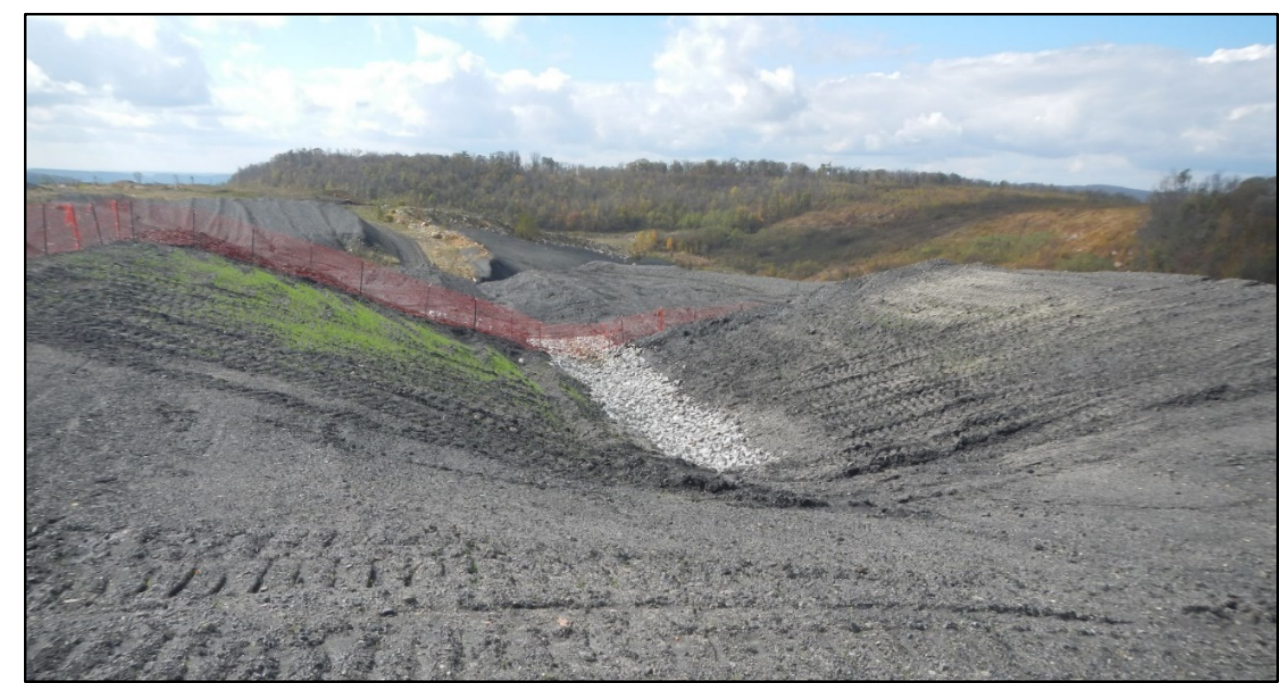

Figure 7. Test plot showing the ongoing revegetation research by Cyphers et al. (in press) Photo courtesy of Levi Cyphers

\subsubsection{Species and seed mixture used for revegetation}

Daniels et al. (1996) and Li and Daniels (1997) report two different seed mixtures that have proved to be successful for revegetation on coal refuse. The seed mixtures are different but they have species in common such as: annual ryegrass, redtop, birdsfoot trefoil, and yellow sweet clover, refer to Table 12. 
Table 12. Species and seed mixture used for revegetation

\begin{tabular}{|c|c|c|c|c|}
\hline & $\begin{array}{l}\text { (Li \& Daniels, } \\
\text { 1997) }\end{array}$ & $\begin{array}{l}\text { (Daniels et al., } \\
\text { 1996) }\end{array}$ & $\begin{array}{l}\text { (Camberato et al., } \\
\text { 2006) }\end{array}$ & $\begin{array}{l}\text { (Laubenstein, } \\
\text { 2004) }\end{array}$ \\
\hline Species used & $\begin{array}{l}\text { KY-31 Tall } \\
\text { fescue, } \\
\text { Annual ryegrass, } \\
\text { Redtop, } \\
\text { Alsike clover, } \\
\text { Alta-swede Red } \\
\text { clover, } \\
\text { Birdsfoot trefoil, } \\
\text { Yellow sweet } \\
\text { clover }\end{array}$ & $\begin{array}{l}\text { Redtop, } \\
\text { Hard fescue, } \\
\text { Tall fescue, } \\
\text { Annual ryegrass, } \\
\text { German millet, } \\
\text { Weeping } \\
\text { lovegrass, } \\
\text { Birdsfoot trefoil, } \\
\text { Yellow sweet } \\
\text { clover, } \\
\text { Ladino clover, } \\
\text { Kobe lespedeza, } \\
\text { Cereal rye }\end{array}$ & Not mentioned & Not mentioned \\
\hline
\end{tabular}

For the current study at Royal Scot, Cyphers et al. (in press) used a mixture of 48\% Annual Rye, 38.76\% of Perennial Rye, and 9.75\% Red Fescue to establish vegetation on the 80/20 and 60/40 Shale/MGro ${ }^{\circledR}$. Based on the conclusion in literature, the Annual Rye specie is among the species which were proved successful. Hence, the probability of vegetation growth resulting from this study would be high. 


\subsection{Literature review of sewage sludge for coal refuse reclamation}

This section examines how sewage sludge has been found to address the problems of shale and how it can promote revegetation and reduce AMD.

\subsubsection{Water holding capacity, surface runoff and temperature}

Sopper (1992) reported that the addition of municipal sludge for land reclamation application decreased the soil water holding capacity, its bulk density, and its temperature. In addition, the surface runoff and erosion are reduced and therefore sedimentation decreases.

A low soil bulk density value is an important parameter because it indicates the ability of the soil to promote root growth, and therefore improve vegetation cover, then consequently reduce the surface runoff and erosion. This advantage of vegetation growth resulted from municipal sludge application aligns with the goal to be reached at the Royal Scot project. Hence, this material is appropriate to use on the site.

\subsubsection{Effect on soil $\mathrm{pH}$}

The literature outlines an augmentation on soil $\mathrm{pH}$ following the application of sewage sludge for revegetation and land reclamation. But instead of using sewage sludge alone, they also mention the use of lime/limestone as complementary material.

For instance, as per Pietz et al. (1989), the combination of sewage sludge and lime is the most effective way to reduce coal refuse acidity and maintaining its $\mathrm{pH}$. They note that "Sewage sludge alone may not be sufficient in ameliorating the acidic conditions in the presence of an abundant supply of pyritic minerals". Joost et al. (1987) report an increase of $\mathrm{pH}$ from 2.7 to 4.45.2 in coal refuse amended with dried sewage sludge and/or limestone. Following the application of municipal sludge and lime on a deep mine anthracite refuse bank, Seaker and Sopper (1983) record a pH increase from 3.7 to 5.4 in 4 years at $0-15 \mathrm{~cm}$ depth. Also, Sopper (1992) notes that the $\mathrm{pH}$ of coal refuse rises from 2.6 to 5.3 when it is amended with municipal sludge at a rate of 450 to $900 \mathrm{Mg} / \mathrm{ha}$, and applied with or without limestone, refer to Table 13. 
Table 13. Liming benefit of sewage sludge application

\begin{tabular}{|l|l|l|l|l|} 
& (Pietz et al., 1989) & (Joost et al., 1987) & $\begin{array}{l}\text { (Seaker \& Sopper, } \\
\text { 1983) }\end{array}$ & (Sopper, 1992) \\
\hline $\begin{array}{l}\text { Liming benefit } \\
\text { after papermill } \\
\text { sludge application }\end{array}$ & $\begin{array}{l}\text { Sewage sludge }+ \\
\text { lime - most } \\
\text { effective in } \\
\text { maintaining refuse } \\
\text { pH and reducing } \\
\text { acidity. }\end{array}$ & $\begin{array}{l}\text { Dried sewage } \\
\text { sludge and/or } \\
\text { limestone }-\mathrm{pH} \\
\text { increased from 2.7 } \\
\text { to 4.4 to 5.2 }\end{array}$ & $\begin{array}{l}\text { Sludge and lime - } \\
\text { initial pH of } \\
\text { refuse increases } \\
\text { from 3.7 to 5.9 in } \\
4 \text { years at 0-15 cm } \\
\text { depth }\end{array}$ & $\begin{array}{l}\text { Sludge (rate of } \\
\text { 450 to 900 Mg/ha) } \\
\text { with/without } \\
\text { limestone - pH of } \\
\text { coal refuse } \\
\text { increased from 2.6 } \\
\text { to 5.3 }\end{array}$ \\
\hline
\end{tabular}

Based on these findings, sewage sludge could be used at Royal Scot site to increase the shale $\mathrm{pH}$. The application of sewage sludge together with lime/limestone may be beneficial as it can increase the shale $\mathrm{pH}$ and thereafter maintain it.

\subsubsection{Pile slope}

The slope is an important factor that influences vegetation growth on coal refuse. This matter shows up in (Sopper, 1992). He points out that the shale slope must be less than 6.7:1 (15\%) for revegetation purpose. However, as stated in Lorimer (2016), some of existing pile at Royal Scot presents a slope greater than 2:1 (50\%) which is definitely not favorable for revegetation. Hence, a major re-grade of the pile is necessary for a successful vegetation cover, bringing the pile from $50 \%$ to less than a $15 \%$ grade.

\subsubsection{Acid Mine Drainage and leachate quality}

Municipal sewage sludge can be used for AMD treatment. But, Seaker and Sopper (1983) noticed that sludge alone is not able to change the groundwater $\mathrm{pH}$. The application of municipal sludge with lime and then followed by revegetation is able to increase the groundwater pH from 4.6 to 6.0 in 4 years (Sopper, 1992).

Based on the recommendations above, municipal sludge with lime should work well at the Royal Scot project site given the objectives of revegetation and AMD treatment. 


\subsubsection{Soil organic content}

Sopper (1992) acknowledges the importance of organic matter content in sludge for soil amendment. In addition, Joost et al. (1987) noticed a rise of coal refuse organic content by 2.0 to 2.5 times compared to the spots amended with limestone or unamended. Hence, sewage sludge is a valuable material for supplying organic content in soil, an essential parameter for a successful revegetation, refer to Table 14 .

Table 14. Effects of sewage sludge application on soil organic content

\begin{tabular}{|l|l|l|l|l|}
\hline & (Pietz et al., 1989) & (Joost et al., 1987) & $\begin{array}{l}\text { (Seaker \& Sopper, } \\
\text { 1983) }\end{array}$ & (Sopper, 1992) \\
\hline $\begin{array}{l}\text { Organic content } \\
\text { capacity }\end{array}$ & Not mentioned & $\begin{array}{l}\text { Sewage sludge } \\
\text { application - } \\
\text { organic matter in } \\
\text { shale increased by } \\
2.0 \text { to 2.5 times } \\
\text { than limestone } \\
\text { amended of } \\
\text { unamended. }\end{array}$ & Not mentioned & $\begin{array}{l}\text { Organic matter } \\
\text { content is the most } \\
\text { beneficial } \\
\text { property of sludge }\end{array}$ \\
\hline
\end{tabular}

\subsubsection{Grass biomass}

During their five-year experience, Seaker and Sopper (1983) noted that yield biomass increases during the first three years of sludge application, and it decreases thereafter. Joost et al. (1987) noticed that the yield biomass is not related to the grass species used. For instance, they observed during their experience, using sewage sludge as an amendment, that the yield biomass from three different grass species is almost the same. Furthermore, the sludge amended plot provided more yield biomass than those amended with organic fertilizers. In summation, sewage sludge is efficient in providing short-term biomass, refer to the Table 15. 
Table 15. Effects of sewage sludge application on grass biomass

\begin{tabular}{|c|c|c|c|c|}
\hline & (Pietz et al., 1989) & (Joost et al., 1987) & $\begin{array}{l}\text { (Seaker \& Sopper, } \\
\text { 1983) }\end{array}$ & (Sopper, 1992) \\
\hline $\begin{array}{l}\text { Grass biomass } \\
\text { after sludge } \\
\text { application }\end{array}$ & Not mentioned & $\begin{array}{l}\text { "Herbage yield } \\
\text { was not } \\
\text { significantly } \\
\text { different among } \\
\text { amended } \\
\text { treatments for any } \\
\text { of the three } \\
\text { grasses." } \\
\text { "Mean herbage } \\
\text { yield of the } \\
\text { grasses exceeded } \\
\text { 4.0 Mg/ha on all } \\
\text { treatments". }\end{array}$ & $\begin{array}{l}\text { "Yields increased } \\
\text { during the first } 3 \\
\text { years following } \\
\text { sludge } \\
\text { application, with } \\
\text { a maximum yield } \\
\text { of } 18 \mathrm{Mg} \text { /ha the } \\
\text { third growing } \\
\text { season. Yields } \\
\text { decreased during } \\
\text { the fourth and } \\
\text { fifth years". }\end{array}$ & $\begin{array}{l}\text { "Larger yield } \\
\text { increases have } \\
\text { been realized on } \\
\text { sludge-amended } \\
\text { mine land than on } \\
\text { the same type of } \\
\text { land amended } \\
\text { with inorganic } \\
\text { fertilizers". }\end{array}$ \\
\hline
\end{tabular}

\subsubsection{Nutrients}

According to Sopper (1992), the macronutrient of forage grasses are the same for sludge amended and inorganic fertilizer amended plots. Seaker and Sopper (1983) emphases that there is no change in the Nitrogen nutrient proportion following sludge application. Therefore, the application of sludge or inorganic fertilizer provide the same results as far as macronutrient proportion is concerned, refer to Table 16.

Table 16. Effects of sewage sludge application on grass nutrients

\begin{tabular}{|l|l|l|l|l|}
\hline & (Pietz et al., 1989) & (Joost et al., 1987) & $\begin{array}{l}\text { (Seaker \& Sopper, } \\
\text { 1983) }\end{array}$ & (Sopper, 1992) \\
\hline Nutrients & Not mentioned & Not mentioned & $\begin{array}{l}\text { "No change in N } \\
\text { after sludge } \\
\text { incorporation.” }\end{array}$ & $\begin{array}{l}\text { "Macronutrient } \\
\text { concentrations of } \\
\text { forages grown on } \\
\text { sludge-amended } \\
\text { spoils are within } \\
\text { the range of } \\
\text { concentrations in } \\
\text { forages grown } \\
\text { with inorganic } \\
\text { fertilizers.” }\end{array}$ \\
\hline
\end{tabular}




\subsubsection{Suggested application rate of sludge for revegetation purposes}

Literature suggests different rates of sludge application according to the objective to be reached whether it is for long-term or short-term vegetation establishment or safe sludge disposal. Additional lime might be needed in some cases.

1. For long-term consideration (more than five years), Pietz et al. (1989) recommend:

- Combination of sludge 134 to 189 dry Mg/ha and lime 900 to $1350 \mathrm{Mg} / \mathrm{ha}$

- Sludge alone with rate of $1050 \mathrm{dry} \mathrm{Mg/ha}$

2. For safe sewage sludge disposal and vegetation persistence, Joost et al. (1987) recommend:

- Sludge rate of $900 \mathrm{Mg} / \mathrm{ha}$

3. For short-term purposes (up to five years), Seaker and Sopper (1983) recommend:

- Stabilized municipal sludge up to $108 \mathrm{dry} \mathrm{Mg/ha} \mathrm{with} \mathrm{lime}$

4. For long-term self-sustaining vegetation and to prevent leaching in groundwater, Sopper (1992) recommend:

- One time application rate of 134 metric tons/ha maximum

- And liming is needed

Based on these recommendations, the fourth option seems to be aligned with the objectives to be reached at Royal Scot site which are: long-term vegetation establishment, self-sustaining vegetation, and reducing AMD generation. Hence, a maximum sludge application of 134 metric tons/ha and additional lime looks promising, refer to Table 17.

Table 17. Recommended rate of sludge

\begin{tabular}{|c|c|c|c|c|}
\hline & (Pietz et al., 1989) & (Joost et al., 1987) & $\begin{array}{l}\text { (Seaker \& Sopper, } \\
\text { 1983) }\end{array}$ & (Sopper, 1992) \\
\hline $\begin{array}{l}\text { Sludge rate used } \\
\text { for revegetation }\end{array}$ & $\begin{array}{l}\text { - Sewage sludge } \\
134 \text { to } 189 \text { dry } \\
\text { Mg/ha + } \\
\text { lime } 900 \text { to } 1350 \\
\text { Mg/ha } \\
\text { - Sludge alone } \\
\text { 1050 dry Mg/ha }\end{array}$ & $\begin{array}{l}\text { Sludge rate of } 900 \\
\mathrm{Mg} / \mathrm{ha}\end{array}$ & $\begin{array}{l}\text { Stabilized } \\
\text { municipal sludge } \\
\text { up to } 108 \text { dry } \\
\text { Mg/ha with lime }\end{array}$ & $\begin{array}{l}\text { One time } \\
\text { application. } \\
\text { Maximum } 134 \\
\text { metric tons/ha } \\
\text { maximum + lime }\end{array}$ \\
\hline
\end{tabular}




\subsubsection{Species and seed mixture used for revegetation}

The literature proposes grass species mixture or alone for the purpose of reclamation, refer to Table 18.

Table 18. Species used for revegetation

\begin{tabular}{|c|c|c|c|c|}
\hline & (Pietz et al., 1989) & (Joost et al., 1987) & $\begin{array}{l}\text { (Seaker \& Sopper, } \\
\text { 1983) }\end{array}$ & (Sopper, 1992) \\
\hline Species used & $\begin{array}{l}\text { Mixture of: } \\
\text { Bromegrass } \\
\text { Tall fescue } \\
\text { Alfalfa }\end{array}$ & $\begin{array}{l}\text { Reed canarygrass, } \\
\text { Tall fescue, } \\
\text { Redtop }\end{array}$ & $\begin{array}{l}\text { Mixture of: } \\
\text { Kentucky-31 tall } \\
\text { fescue, } \\
\text { Pennlate } \\
\text { orchardgrass, } \\
\text { Penngift } \\
\text { crownvetch, and } \\
\text { Empire Birdsfoot } \\
\text { trefoil }\end{array}$ & $\begin{array}{l}\text { Tall fescue, } \\
\text { Redtop, and } \\
\text { Reed canarygrass }\end{array}$ \\
\hline
\end{tabular}

Among the advised species, Joost et al. (1987) concluded that: Reed canarygrass is the most persistent grass and Tall fescue has the poorest persistence. Also, Sopper (1992) outlines that the Redtop specie was the most successful.

Based on the above findings, Redtop specie is recommended for the Royal Scot site. Reed canarygrass is also an option to consider. 


\subsection{Literature review of lumber mill waste (or wood residue or wood waste) for coal refuse reclamation}

The application of lumber mill waste may be another option to reclaim and revegetate this site; however, information on the use of wood residue for coal refuse reclamation is limited. That said, it is known that wood waste cover provides certain advantages such as the ability to enhance the spoil structure, permeability, infiltration rate and therefore promote plant establishment and growth (Voorhees, 1986). It has also been proven that wood waste material is successful in revegetating and promoting environmental conditions of other mining waste such as bentonite mine spoils (Schuman \& Sedbrook, 1984). Referring to the grain-size of bentonite compared to shale, it seems that bentonite has more fine particles (56.6\%) compared to shale (15\%). Lunt (1955) found a great soil improvement (soil structure, organic matter content) by applying wood residue on coarse-grained soil. This indicates that applying wood residue to the coal refuse, which contains more coarse particles than bentonite, might enhance the ability of the soil to promote revegetation.

Table 19. Particles size distribution of bentonite spoil vs. coal refuse

\begin{tabular}{|l|l|l|}
\hline Particle-size separates, \% & $\begin{array}{l}\text { Bentonite spoil } \\
\text { (J. A. Smith et al., 1985) }\end{array}$ & $\begin{array}{l}\text { Coal refuse } \\
\text { (Stewart \& Daniels, 1992) }\end{array}$ \\
\hline Gravel & N/A & $60 \%$ \\
\hline Sand & $10.8 \% \pm 0.8$ & $25 \%$ \\
\hline Silt & $29.6 \% \pm 0.8$ & \\
\hline Clay & $56.6 \% \pm 1.1$ & $15 \%$ \\
\hline
\end{tabular}

Moreover, the literature reveals that the addition of wood waste to soil develops vegetation establishment and soil productivity. Vegetation, in its turn, will improve physical properties of soil by rising the soil organic matter, decreasing the soil bulk density, and moderating soil $\mathrm{pH}$ (Sheoran et al., 2010). The research conducted by Packer and Aldon (1978) showed that applying wood residue at two to three times the level of straw mulch helped to limit erosion and boost revegetation.

As for AMD treatment, Reardon and Poscente (1984) reported that wood waste can be used as an oxygen interceptor for pyritic tailings which results in a reduction of acidity generation and 
consequently in reduction of AMD. Germain, Tassé, and Cyr (2003) also supports the idea that organic cover such as wood waste can accomplish the role of oxygen barrier and treat transient acidogenic waters. From a laboratory experiment, Markovic et al. (2011) concluded that sawdust application is able to remove heavy metals (iron, zinc, nickel, copper) from AMD. Likewise, Božić, Stanković, Gorgievski, Bogdanović, and Kovačević (2009) found that sawdust can help adsorb heavy metals (zinc, nickel, cadmium, manganese, ion) from AMD.

Sheoran et al. (2010) notes that even if wood waste can procure the necessary initial mine soil organic matter, it is deficient in nitrogen. Thus, heavy fertilizer application, especially nitrogen, is needed for vegetation establishment (Daniels \& Zipper, 2010). Smith (1984) recommends the application of 90 ton/ha of wood residue for efficient vegetation establishment. Moreover, Vogel (1981) suggested an additional 7.5 to $12.5 \mathrm{~kg} \mathrm{~N} / \mathrm{t}$ of wood residue for N-deficient mine soils. Rainbow (2012), who presented the testing performed at Glasgow University's Department of Agricultural Chemistry, discussed that blending coal spoil with wood waste can boost the ability of the soil for revegetation by improving its properties (water and nutrient holding). The report suggests a successful proportion of wood waste:coal spoil ranging from 1:1 to 1:2. The results of this research also found even more improvement of soil properties using a blend composed of coal spoil, wood waste and sewage sludge. Mannion (2014) affirms that wood waste provides organic matter while sewage sludge supplies nitrogen to the soil.

In summary, wood residue shows promise in revegetation and presents environmental benefits. It can reduce erosion, decrease AMD generation, and promote vegetation cover. For these reasons, it could be successful if applied at the Royal Scot site. 


\section{DISCUSSION AND RECOMMENDATIONS}

The purpose of this report was to reveal how the literature describes the effectiveness of three topsoil substitutes: papermill sludge, sewage sludge and lumber mill waste. When comparing these three substitutes in the context of the current conditions and objectives at the Royal Scot site, it appears that papermill sludge and sewage sludge offer the best results.

Table 20 present a comparison between papermill and sewage sludges, focuses on the specific issues of erosion, AMD reduction, and revegetation.

Table 20. Papermill vs. sewage sludge for application at Royal Scot

\begin{tabular}{|c|c|c|}
\hline & Papermill sludge & Sewage sludge \\
\hline Erosion & $\begin{array}{l}\text { Improves soil water holding capacity } \\
\text { and infiltration, reduces surface runoff } \\
\text { Moderate surface temperature }\end{array}$ & $\begin{array}{l}\text { Decreases soil water holding capacity, } \\
\text { runoff, surface erosion and sedimentation }\end{array}$ \\
\hline AMD & $\begin{array}{l}\text { - Increases the soil pH and stabilizes it } \\
\text { - Reduces AMD generation } \\
\text { - Improves leachate quality }\end{array}$ & Increases soil $\mathrm{pH}$ and maintains it \\
\hline Revegetation & $\begin{array}{l}\text { Increases soil organic matter and yield } \\
\text { biomass } \\
\text { Decreases soil bulk density and surface } \\
\text { temperature }\end{array}$ & $\begin{array}{l}\text { - Supplies organic content to soil } \\
\text { - Decreases the soil bulk density that can } \\
\text { promote vegetation root growth }\end{array}$ \\
\hline $\begin{array}{l}\text { Necessary } \\
\text { supplement } \\
\text { material }\end{array}$ & Fertilizer and lime & Lime/limestone \\
\hline Availability & $\sim 55$ miles & $\sim 25$ to 45 miles \\
\hline
\end{tabular}

Table 20 shows that the effect of papermill and sewage sludges application on soil are similar in some ways, they both:

- Improve the water holding capacity and reduces surface runoff, which helps to reduce soil erosion and sedimentation

- Increase the soil pH, thus reducing AMD generation

- Increase soil organic matter and decrease bulk density, which is essential for vegetation growth

But they also reveal major differences that may impact significantly the cost of revegetation: 
- While papermill sludge application require fertilizer and lime supplement, the sewage sludge only needs lime or limestone.

- Sewage sludge is more accessible being approximately 25 to 45 miles away from the Royal Scot site compared to the papermill sludge supply, which is about 55 miles away.

Hence, it appears that both papermill and sewage sludge are well-suited materials to deal with the issues at Royal Scot, but sewage sludge might be the one which provides greater results especially in term of cost.

Table 21 summarizes the best practices and advisable methods that appears to be applicable for coal refuse pile. It proposes recommendations that should be fully considered for the long-term goal to revegetate the Royal scot refuse pile. 
Table 21. Best practices for field application of papermill and sewage sludge

\begin{tabular}{|c|c|c|}
\hline & Papermill sludge & Sewage sludge \\
\hline Soil pH & N/A & $\begin{array}{l}\text { More efficient to increase and maintain } \\
\text { acidic soil } \mathrm{pH} \text { when applied with } \\
\text { lime/limestone }\end{array}$ \\
\hline Pile slope & N/A & Must be $<15 \%(6.7 \mathrm{H}: 1 \mathrm{~V})$ \\
\hline $\begin{array}{l}\text { Water holding } \\
\text { capacity }\end{array}$ & $\begin{array}{l}\text { Mix fine and coarse refuse on the final } \\
\text { layer to have maximum profit of water } \\
\text { holding capacity }\end{array}$ & N/A \\
\hline Organic matter & $\begin{array}{l}\text { High sludge rate is recommended to } \\
\text { obtain a persistent organic matter }\end{array}$ & N/A \\
\hline Yield & $\begin{array}{l}\text { Sludge with low N-fertilizer is } \\
\text { recommended for higher yields }\end{array}$ & N/A \\
\hline AMD & $\begin{array}{l}\text { - Application of SPF was successful } \\
\text { - Blend with lime for long-term effect }\end{array}$ & $\begin{array}{l}\text { - Sludge + lime have proved to work } \\
\text { well to increase significantly } \\
\text { groundwater pH } \\
\text { - Sludge alone is not enough for AMD } \\
\text { treatment }\end{array}$ \\
\hline $\begin{array}{l}\text { Sludge rate } \\
\text { suggested }\end{array}$ & $\begin{array}{l}75 \% \text { SPF, 25\% shale, plus proper } \\
\text { nutrients }\end{array}$ & $\begin{array}{l}\text { One time sludge application of } 134 \\
\text { metric tons.ha }{ }^{-1} \text { maximum is sufficient } \\
\text { for long-term sustainable vegetation and } \\
\text { to lower AMD generation. The } \\
\text { combination with lime is necessary for } \\
\text { successful result }\end{array}$ \\
\hline $\begin{array}{l}\text { Species } \\
\text { recommended }\end{array}$ & $\begin{array}{l}\text { - Annual ryegrass } \\
\text { - Redtop } \\
\text { - Birdsfoot trefoil } \\
\text { - Yellow sweet clover }\end{array}$ & $\begin{array}{l}\text { - Redtop } \\
\text { - Reed canarygrass }\end{array}$ \\
\hline
\end{tabular}

N/A: Not available

As for the third substitute, wood residue, it could be a potential material for revegetating coal refuse material. When applied with $\mathrm{N}$-fertilizer, it has been proved to be effective in other mine spoil reclamation. However, further research and experimentation are needed to determine its effectiveness on coal refuse. 
In conclusion, the application of sludges on soil provides positive effects, but they may also bring unexpected outcomes. To avoid and understand these, it is recommended to characterize the sludge beforehand, such as running tests to determine:

- Physicochemical parameters

- Total and bioavailable heavy metals (Cd, Cr, Cu, Ni, Pb, Zn, and Hg)

- Organic contaminants

- Pathogenic microorganisms

- Stability and phytotoxicity indicators (Alvarenga et al., 2015). 


\section{CONCLUSION}

This report concludes that papermill and sewage sludges are suitable solutions for revegetating shale. When comparing the two, sewage sludge seems the most effective material to deal with the short-term and most urgent issue at the Royal Scot site which is the AMD and does so in a way that follows a source control approach. When combined with lime, sewage sludge also appears to be effective for meeting the long-term goal of revegetating the site in a sustainable way. As for the third method, the application of wood residue, it could be an alternative material but still requires further research.

The findings from this study provide insights to the mining industry about the materials and methods that can be applied for reclaiming and revegetating coal refuse. This report also contributes to the understanding of sewage sludge which can be a substitute of papermill sludge that is currently proposed on Royal Scot site. These observations can open doors to other research topics as well, such as the application of wood residue for coal refuse reclamation, the cost-effectiveness of sewage sludge application to Royal Scot site; and the application of sewage sludge can be incorporated as part of a coal refuse restoration plan as well. 


\section{REFERENCES}

Akcil, A., \& Koldas, S. (2006). Acid Mine Drainage (AMD): causes, treatment and case studies. Journal of Cleaner Production, 14(12), 1139-1145.

American Society for Testing and Materials (1991). Annual Book of ASTM Standards, Vol. 04.08. Philadelphia, PA

Alvarenga, P., Mourinha, C., Farto, M., Santos, T., Palma, P., Sengo, J., ... \& Cunha-Queda, C.

(2015). Sewage sludge, compost and other representative organic wastes as agricultural soil amendments: Benefits versus limiting factors. Waste management, 40, 44-52.Božić, D., Stanković, V., Gorgievski, M., Bogdanović, G., \& Kovačević, R. (2009). Adsorption of heavy metal ions by sawdust of deciduous trees. Journal of hazardous materials, 171(1), 684-692.

Camberato, J. J., Gagnon, B., Angers, D. A., Chantigny, M. H., \& Pan, W. L. (2006). Pulp and paper mill by-products as soil amendments and plant nutrient sources. Canadian journal of soil science, 86(4), 641-653.

Cyphers, L. J., Hopkinson, L., \& Quaranta, J. (2018). Exploring the use of short paper fiber as a soil amendment in coal refuse. Proceedings of the West Virginia Academy of Science, 89(1). In press

D’Appolonia Consulting Engineers Inc., (2009). “Engineering and Design Manual Coal Refuse Disposal Facilities, $2^{\text {nd }}$ ed., U.S. Department of Labor, Mine Safety and Health Administration [MSHA].

Daniels, W. L., Stewart, B. R., \& Dove, D. C. (1995). Reclamation of coal refuse disposal areas. Va. Coop. Ext. Pub, 460, 131.

Daniels, W. L., Stewart, B. R., \& Zipper, C. E. (1996). Reclamation of coal refuse disposal areas. Publication Number 460-131, June 1996. Updated 2009. Pre-publication draft.

Daniels, W. L., \& Zipper, C. E. (2010). Creation and management of productive minesoils. Va. Coop. Ext. Pub, 460, 121.

Food and Agriculture Organization. Key definitions. Retrieved from http://www.fao.org/soilsportal/about/all-definitions/en/ on Jan 15, 2018

Germain, D., Tassé, N., \& Cyr, J. (2003). Treatment of acid mine effluents using a woodwaste cover. In Proceedings of Sudbury (pp. 1-9).

Hopkinson, L. C., Lorimer, J. T., Stevens, J. R., Russell, H., Hause, J., Quaranta, J. D., \& Ziemkiewicz, P. F. (2017). Geomorphic landform design principles applied to an abandoned coal refuse pile in central appalachia1. Journal American Society of Mining and Reclamation, 6(2), 19-36.

Izu, P., Zulueta, A., \& Salas, O. (1997). Laboratory testing of several paper sludges as raw materials for landfill covers. Paper presented at the first international workshop on the use of paper industry sludges in environmental geotechnology and construction, Helsinki, Finland.

Johnson, D. B., \& Hallberg, K. B. (2005). Acid mine drainage remediation options: A review. Science of the Total Environment, 338(1), 3-14.

Joost, R. E., Olsen, F. J., \& Jones, J. H. (1987). Revegetation and minesoil development of coal refuse amended with sewage sludge and limestone. Journal of Environmental Quality, 16(1), 65-68. 
Kulling, D., Stadelmann, F., Herter, U. (2001). Sewage Sludge - Fertilizer or Waste? UKWIR Conference, Brussels.

Laubenstein, J. (2004). Beneficial use of short paper fiber (paper mill sludge) for pollution prevention in the mining industry. In TAPPI Paper Summit-Spring Technical and International Environmental Conference.

Laubenstein, J. W., \& Field, S. (1994, 1994). Utilization of Short Paper Fiber (SPF) in the Manufacturing of Synthetic Soils Used for Capping Landfills. In TAPPI International Environmental Conference (pp. 355-355). TAPPI press.

Li, R. S., \& Daniels, W. L. (1997). Reclamation of coal refuse with a papermill sludge amendment. In Proc., 1997 Annual Meeting of the Amer. Soc. For Surf. Mining and Rec., Austin, TX (pp. 277-290).

Lorimer, J. T. (2016). Geomorphic Landform Design Principles Applied to an Abandoned Coarse Coal Refuse Pile on Steep Terrain in Central Appalachia. (M.S. Thesis), West Virginia University, Morgantown, WV.

Lunt, H. A. (1955). The use of woodchips and other wood fragments as soil amendments

(Bulletin / connecticut agricultural experiment station, no. 593). New Haven: Connecticut Agricultural Experiment Station.

Madigan, M., \& Martinko, J. (2006). Brock biology of microorganisms 11th ed. ed.). Upper Saddle River, N.J.: Prentice Hall.

Maltby, V. (2005). Compilation of alternative landfill cover experience using wastewater treatment plant residuals: NCASI.

Mannion, A. (2014). Global environmental change: a natural and cultural environmental history: Routledge.

Markovic, R., Stevanovic, J., Stevanovic, Z., Bugarin, M., Nedeljkovic, D., Grujic, A., \& StajicTrošic, J. (2011). Using the low-cost waste materials for heavy metals removal from the mine wastewater. Materials Transactions, 52(10), 1849-1852.

McKeever, D. B. (2004). Inventories of woody residues and solid wood waste in the United States, 2002. In 9th International Conference on Inorganic-Bonded Composite Materials, Vancouver, Canada, October (pp. 10-13).

Moo-Young, H. K., \& Zimmie, T. F. (1996). Geotechnical properties of paper mill sludges for use in landfill covers. Journal of Geotechnical Engineering, 122(9), 768-775.

Packer, P. E., \& Aldon, E. F. (1978). Revegetation techniques for dry regions. Reclamation of Drastically Disturbed Lands. American Society of Agronomy, 425-450.

Park, R. (2017). Geotechnical Laboratory Testing for 2-D FEM Analysis of Geomorphic and Planar Sloped Caps and Covers for Sustainable Mine Refuse Deposition. (M.S. Thesis), West Virginia University, Morgantown, WV,

Pietz, R. I., Carlson, C. R., Peterson, J. R., Zenz, D. R., \& Lue-Hing, C. (1989). Application of sewage sludge and other amendments to coal refuse material: II. Effects on revegetation. Journal of Environmental Quality, 18(2), 169-173.

Rainbow, A. K. M. (2012). Reclamation, treatment and utilization of coal mining wastes: Elsevier.

Reardon, E. J., \& Poscente, P. J. (1984). A study of gas compositions in sawmill waste deposits: Evaluation of the use of wood waste in close-out of pyritic tailings. Reclamation and Revegetation Research, 3(2), 109-128.

Santos, I. (2017). 3D Finite Element Seepage and Slope Stability Modeling of a Geomorphic Landform Reclamation. (M.S. Thesis), West Virginia University, Morgantown, WV. 
Schuman, G. E., \& Sedbrook, T. A. (1984). Sawmill wood residue for reclaiming bentonite spoils. Forest products journal.

Seaker, E. M., \& Sopper, W. E. (1983). Reclamation of deep mine refuse banks with municipal sewage sludge. Waste Management \& Research, 1(4), 309-322.

Sheoran, V., Sheoran, A. S., \& Poonia, P. (2010). Soil reclamation of abandoned mine land by revegetation: a review. International Journal of Soil, Sediment and Water, 3(2), 13.

Simpson, P. T., \& Zimmie, T. F. (2005). Waste Paper Sludge-An Update on Current Technology and Reuse. In Recycled Materials in Geotechnics (pp. 75-90).

SME Mining Engineering Handbook. (1973). Port City Press, Baltimore, Maryland, United States.

Smith, J. A. (1984). Wood residue and fertilizer amendments for reclamation of orphan bentonite mine spoils. (Doctoral dissertation, University of Wyoming).

Smith, J. A., Schuman, G. E., De Puit, E. J., \& Sedbrook, T. A. (1985). Wood residue and fertilizer amendment of bentonite mine spoils: I. Spoil and general vegetation responses. Journal of Environmental Quality, 14(4), 575-580.

Singh, R. P., \& Agrawal, M. (2008). Potential benefits and risks of land application of sewage sludge. Waste management, 28(2), 347-358.

Sopper, W. E. (1992). Reclamation of mine land using municipal sludge. In Soil Restoration (pp. 351-431): Springer.

Stevens, J. R. (2016). Geotechnical testing and Finite Element Modeling of Geomorphic Landform Design with a Multi-Layer Cap and Cover System. (M.S. Thesis), West Virginia University, Morgantown, WV.

Stewart, B. R., \& Daniels, W. L. (1992). Physical and chemical properties of coal refuse from southwest Virginia. Journal of Environmental Quality, 21(4), 635-642.

Stichler, C. (2002). Grass growth and development. Texas Cooperative Extension, Texas A\&M University System. In.

Tolikonda, R. (2010). Nonwoven Geotextile Filtration Performance with Coal Refuse. (M.S. Thesis), West Virginia University, Morgantown, WV.

Tordoff, G. M., Baker, A. J. M., \& Willis, A. J. (2000). Current approaches to the revegetation and reclamation of metalliferous mine wastes. Chemosphere, 41(1), 219-228.

USDA Natural Resources Conservation Service, \& Pullman Plant Materials Center. (2005). Terminology and definitions associated with revegetation (Technical notes, plant materials, no. 9 (Spokane, washington)).

Vasconcelos, E., \& Cabral, F. (1993). Use and environmental implications of pulp-mill sludge as an organic fertilizer. Environmental pollution, 80(2), 159-162.

Vogel, W. G. (1981). Guide for revegetating coal minesoils in the Eastern United States (No. PB81-245011; GTR-NE-68). Forest Service, Broomall, PA (USA). Northeastern Forest Experiment Station.

Voorhees, M. E. (1986). Infiltration rate of bentonite mine spoil as affected by amendments of gypsum, sawdust and inorganic fertilizer. Reclamation and Revegetation Research, 5(4), 483-490.

Ward, K. (2001). “A toxic legacy.” Charleston Gazette-Mail. Retrieved from: http://www.wvgazettemail.com/article/20010812/ARTICLE/308129998/

Wurzburger, S. R., \& Overton, J. M. (1997). Treatment for acid mine drainage. In: Google Patents. 
Younos, T. M., \& Smolen, M. D. (1981). Simulation of infiltration in a sewage sludge amended mine soil. In Proc. Symp. on Surface Mining Hydrol., Sedimentol., and Reclamation (pp. 319-324).

Zhan, T. L., Zhan, X., Lin, W., Luo, X., \& Chen, Y. (2014). Field and laboratory investigation on geotechnical properties of sewage sludge disposed in a pit at Changan landfill, Chengdu, China. Engineering Geology, 170, 24-32. 